\title{
Ocorrência de Theileria equi congênita em potros Puro Sangue Lusitano no Brasil, diagnosticada através da técnica de RT-PCR
}

Tese apresentada ao Programa de Pós-Graduação em Clínica Veterinária da Faculdade de Medicina Veterinária e Zootecnia da Universidade de São Paulo para obtenção do título de Doutor em Medicina Veterinária

Departamento:

Clínica Médica

Área de concentração:

Clínica Veterinária

Orientador:

Prof. Dr. Wilson Roberto Fernandes 
Autorizo a reprodução parcial ou total desta obra, para fins acadêmicos, desde que citada a fonte.

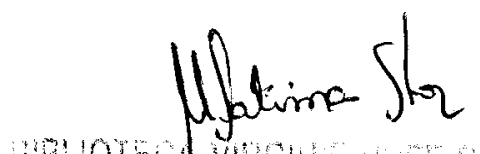

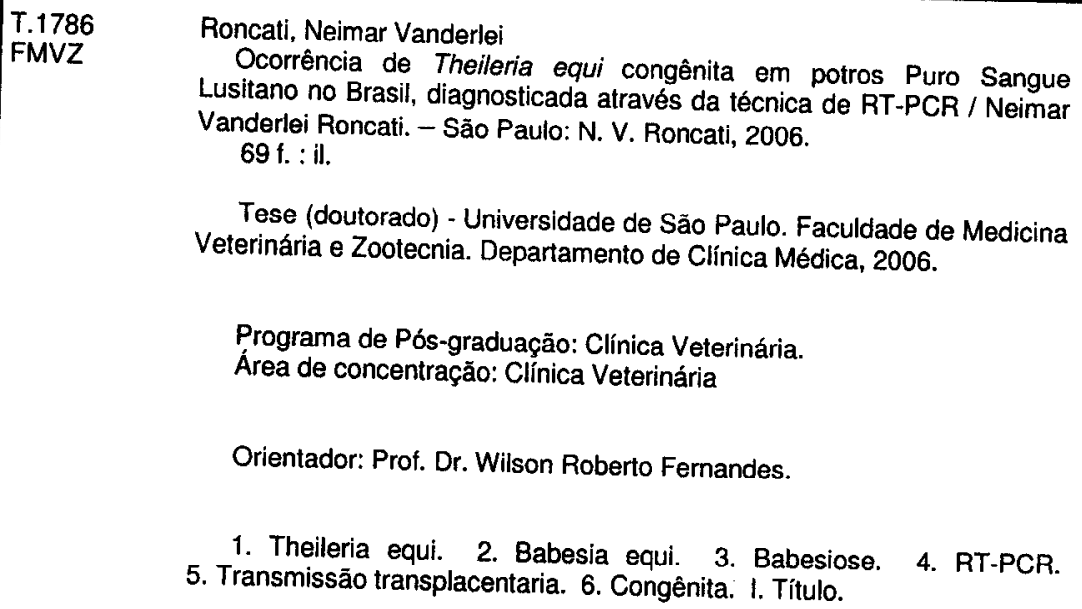

Tese (doutorado) - Universidade de São Paulo. Faculdade de Medicina Veterinária e Zootecnia. Departamento de Clínica Médica, 2006.

Programa de Pós-graduação: Clínica Veterinária.

Área de concentração: Clínica Veterinária

Orientador: Prof. Dr. Wilson Roberto Fernandes.

1. Theileria equi. 2. Babesia equi. 3. Babesiose. 4. RT-PCR. 5. Transmissão transplacentaria. 6. Congênita. I. Título. 


\section{UNIVERSIDADE DE SÃO PAULO \\ Faculdade de Medicina Veterinária e Zootecnia \\ Comissão de Bioética}

\section{PARECER}

Interessado: Neimar Vanderlei Roncati

Assunto: Protocolo de experimentação adotado em experimento anim

A Comissão de Bioética da Faculdade de Medicina Veterinária e Zor da Universidade de São Paulo, após analisar o projeto protocolado número 988/2006, intitulado: “Ocorrência de Theileria equi congêni potros puro sangue lusitanos", no qual foram utilizados 100 (cem) eq sob responsabilidade do Prof. Dr. Wilson Roberto Fernandes, constatc o mesmo foi realizado de acordo com os princípios de bioética, adc por esta Comissão.

São Paulo, 18 de outubro de 2006

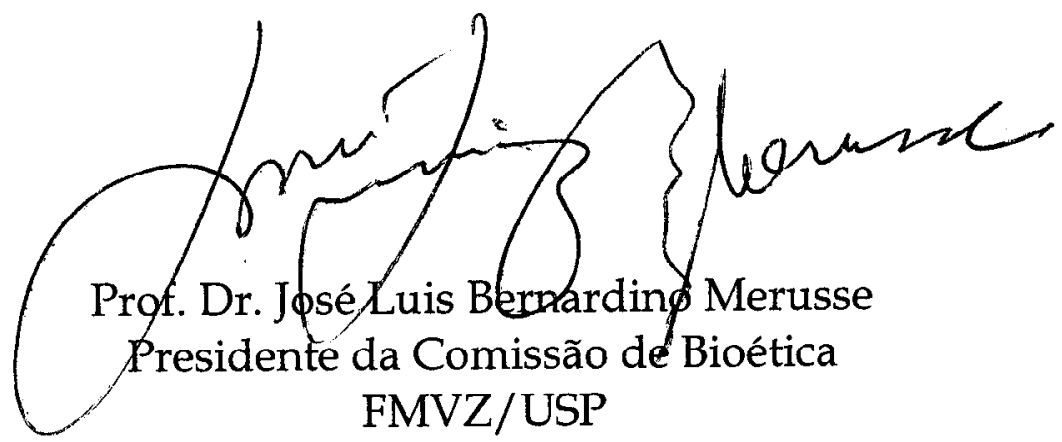




\section{FOLHA DE AVALIAÇÃO}

Nome: RONCATI, Neimar Vanderlei

Título: Ocorrência de Theileria equi congênita em potros Puro Sangue Lusitano no Brasil, diagnosticada através da técnica de RT-PCR

Tese apresentada ao Programa de PósGraduação em Clínica Veterinária da Faculdade de Medicina Veterinária e Zootecnia da Universidade de São Paulo para obtenção do título de Doutor em Medicina Veterinária

Data da Defesa: 1

Banca Examinadora

Prof. Dr. Instituição:

Julgamento: Assinatura:

Prof. Dr. Instituição:

Julgamento: Assinatura:

Prof. Dr. Instituição:

Julgamento: Assinatura:

Prof. Dr. Instituição:

Julgamento: Assinatura:

Prof. Dr. Instituição:

Julgamento: Assinatura: 
À minha incansável mãe Edi, por seu inabalável amor; assim como ao meu irmão João pela amizade. Ao meu irmão Raymundo e pai João (in memorian), por vossa breve, mas duradoura dedicação à minha formação. À minha querida Gabriela pela forte presença em tudo e todo o tempo. 


\section{AGRADECIMENTOS}

Ao Prof. Dr. Wilson Roberto Fernandes, pela maestria no ensino do melhor caminho.

À profa. Dra. Raquel Baccarin, pelas idéias que iluminaram este trabalho.

À profa. Dra. Cristina Massoco, pela sua disponibilidade e presteza no auxílio à construção deste trabalho.

Aos profissionais do Laboratório Genoa, pela pronta e imprescindível ajuda na realização do trabalho.

À Marise e Silvio Piotto, do laboratório Equalli, sempre prontos ao auxílio profissional para realização deste trabalho.

À amiga Prof. Dra. Sandra Satiko Kitamura pelo auxílio no dia a dia.

Aos amigos Roberto de Andrade Bordim, André Monteiro da Rocha e César Dinola Pereira, brilhantes professores e auxiliadores.

Ao amigo e excelente profissional, médico veterinário Alexander Bloem pelo auxílio nas colheitas das amostras.

À Adelaide pela sempre pronta ajuda nestes longos anos.

À Faculdade de Medicina Veterinária e Zootecnia da USP, lar onde este trabalho foi realizado.

Às pessoas que estruturam o curso de Medicina Veterinária da Universidade Anhembi Morumbi pelo prazer de ensinar.

Aos eqüinos, fonte de inspiração e energia de viver na sua demonstração de majestade e força.

A Deus pela oportunidade de viver.

A você. 


\section{RESUMO}

RONCATI, N. V. Ocorrência de Theileria equi congênita em potros Puro Sangue Lusitano no Brasil, diagnosticada através da técnica de RT-PCR. [Occurrence of congenital Theileria equi in Lusitano foals through RT-PCR detection]. 2006. $69 \mathrm{f}$. Tese (Doutorado em Medicina Veterinária) - Faculdade de Medicina Veterinária e Zootecnia, Universidade de São Paulo, São Paulo, 2006.

Para determinação da ocorrência de transmissão transplacentária da Theileria equi em neonatos eqüinos foram avaliados 50 potros da raça Puro Sangue Lusitano, machos e fêmeas, bem como suas respectivas mães, logo após o parto. Foram colhidas amostras de sangue total, tanto das mães como dos neonatos, entre as primeiras cinco horas pós parto para pesquisa de Theileria equi e Babesia caballi através da técnica de RT-PCR. Utilizou-se o kit de detecção baseado no fluofóro intercalante de DNA SYBERgreen. Um total de $46 \%$ das éguas apresentaram resultado positivo para Theileira equi e $54 \%$ se mostraram negativas, enquanto que $66 \%$ dos potros apresentaram resultados positivos e $34 \%$ negativos, sendo que $73,9 \%$ dos potros positivos nasceram de mães também positivas. Já para Babesia caballi, $16 \%$ das éguas foram positivas e $84 \%$ negativas, assim como $2 \%$ dos potros foram positivos e $98 \%$ negativos. O teste de RT-PCR é bastante sensível e específico, mas pode resultar em falso negativo, apesar de ser eficaz na detecção da Theileria equi e Babesia caballi nos eqüinos. Estes dados permitem concluir que existe a possibilidade de transmissão transplacentária de Theileria equi.

Palavras-chave: Theileria equi. Babesia equi. Babesiose. RT-PCR. Transmissão transplacentária. Congênita. 


\begin{abstract}
RONCATI, N. V. Occurrence of congenital Theileria equi in Lusitano foals through RT-PCR detection. [Ocorrência de Theileria equi congênita em potros Puro Sangue Lusitano no Brasil, diagnosticada através da técnica de RT-PCR]. 2006. 69 f. Tese (Doutorado em Medicina Veterinária) - Faculdade de Medicina Veterinária e Zootecnia, Universidade de São Paulo, São Paulo, 2006.
\end{abstract}

The occurrence of transplacentary transmission of Theileria equi in horses was determined by evaluating 50 young male and female horses of the breed Lusitano Horses as well as their respective mothers. Colts and fillies were evaluated as soon as they were born. Total blood samples were collected from both mother and offspring within the first five hours right after the parturition to analyse Theileria equi and Babesia caballi through the RT-PCR technique. It was used the kit of detection based on DNA SYBERgreen. This study showed us that $46 \%$ of the female horses had positive results for Theileira equi and 54\% negative results while $66 \%$ of the male horses had positive results and $34 \%$ of them, negative ones. Moreover, $73.9 \%$ of the positive young horses also had their mothers positive. However, for Babesia caballi $16 \%$ of the female horses had positive results and $84 \%$ negative ones while $2 \%$ of the male horses had positive results and 98\%, negative ones. The RT-PCR test is very sensitive and specific but it can occur false-negative results although it is efficient in detecting Theileria equi and Babesia caballi in horses. In conclusion, the data show us that there is a possibility of transplacentary transmission of Theileria equi.

Key words:Theileria equi. Babesia equi. RT-PCR. Congenital. Transplacentary transmission. Babesiosis. 


\section{LISTA DE GRÁFICOS}

Gráfico 1 - Representação da porcentagem de potros nascidos positivos para Theileria equi no teste de RT-PCR - São Paulo, 2006.

Gráfico 2 - Representação da porcentagem de éguas negativas ou positivas para Theileria equi em relação aos neonatos positivos ou negativos, no teste de RT-PCR - São Paulo, 2006

Gráfico 3 - $\quad$ Representação da porcentagem de potros nascidos positivos para Babesia caballi no teste de RT-PCR - São Paulo, 2006.

Gráfico 4 - Representação da porcentagem de éguas negativas ou positivas para Babesia caballi em relação aos neonatos positivos ou negativos, no teste de RT-PCR - São Paulo, 2006

Gráfico 5 - Representação da porcentagem de potros positivos para Theileria equi, nascidos de éguas também positivas no teste de RT-PCR e cELISA - São Paulo, 2006.

Gráfico 6 - Representação da porcentagem de potros positivos para Theileria equi, nascidos de éguas também positivas no teste de RT-PCR - São Paulo, 2006. 


\section{LISTA DE TABELAS}

Tabela 1 - Resultado de RT-PCR para Theileira equi nas éguas e potros ao primeiro dia de nascimento - São Paulo, 2006.

Tabela 2 - $\quad$ Resultado de RT-PCR para Babesia caballi nas éguas e potros ao primeiro dia de nascimento - São Paulo, 2006.

Tabela 3 - $\quad$ Resultado do teste de cELISA para Theileria equi das éguas testadas negativas no teste de RT-PCR com potros nascidos positivos no mesmo teste - São Paulo, 2006. 


\section{LISTA DE ILUSTRAÇÕES}

Quadro 1 - Seqüência dos oligonucleotídeos utilizados no ensaio de RTPCR para detecção de $T$. equi e B. caballi - São Paulo, 2006...

Apêndice 2 - Resultado de RT-PCR tanto para Babesia caballi como para Theileira equi nas éguas e potros ao primeiro dia de nascimento. 
2.1 BABESIA.

2.1 TRANSMISSÃO.

2.6 DIAGNÓSTICO.

2.6.3 Ensaio imunoenzimático (ELISA). 


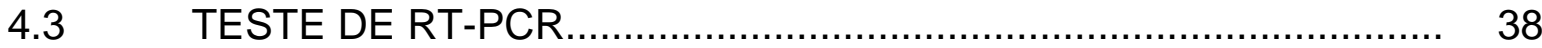

4.3.1 Isolamento e precipitação do DNA ....................................... 39

4.3.2 Técnica de detecção de T. equi e B. caballi............................... 39

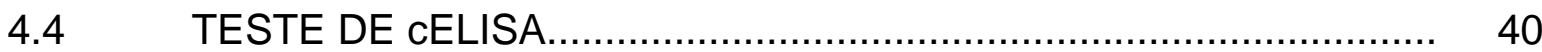

$5 \quad$ ANÁLISE ESTATÍSTICA

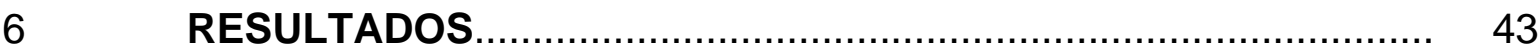

DISCUSSÃO

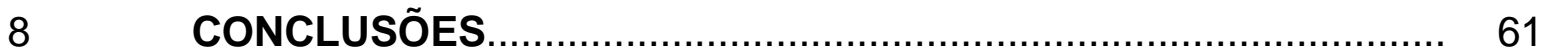

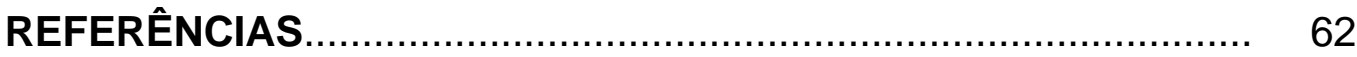




\section{INTRODUÇÃO}

A Babesiose eqüina é uma importante afecção parasitária que acomete os eqüinos de forma endêmica no território Brasileiro assim como em diversos outros países do mundo todo. Esta afecção vem sendo estudada a dezenas de anos, principalmente em função do elevado número de distúrbios que pode acarretar individualmente aos animais acometidos, bem como em todo o plantel sem se subestimar as enormes perdas econômicas na equideocultura mundial.

As condições climáticas encontradas em países tropicais como o Brasil são propícias à existência de muitos ácaros, dentre eles diversas espécies de carrapatos, parasitas importantes na propagação e manutenção da transmissão natural da babesia para os hospedeiros eqüinos.

Muitos trabalhos científicos tentam comprovar ou pelo menos elucidar quais espécies de carrapatos estão envolvidos no processo de transmissão tanto da Babesia caballi, como da Babesia equi, mas nesta segunda espécie poucos avanços foram conseguidos, justamente pela incapacidade de comprovação de qual a espécie de carrapato é responsável pela manutenção dos altos índices de prevalência da Babesiose, tornando nosso país conhecido e oficialmente registrado na OIE (Office International des Epizooties) como um país endêmico. Esta mesma organização classifica a Piroplasmose Eqüina (Babesiose) como sendo uma doença da lista "B", ou seja, definida como doença transmissível e de importância sócio-econômica e/ou saúde pública e que são significativas no comércio internacional de animais. 
Não diferente são as dificuldades encontradas no tratamento dos animais doentes ou mesmo portadores destes protozoários, já que a maioria dos medicamentos hoje utilizados são bastante eficazes no combate da Babesia caballi, mas quase ou totalmente ineficazes na terapia da Babesia equi, tornando esta última um problema na criação de eqüinos já que pode causar danos diretos como perda de rendimento, anemia, cólica, abortamentos, e indiretos como dificuldade no transporte internacional dos eqüinos.

Países ricos como os Estados Unidos que investem grandes montantes nas pesquisas científicas não se interessam pelo investimento em novos produtos para terapia desta doença considerada exótica para eles. Já em paises menos beneficiados economicamente, mas muito interessados nesta doença como o Brasil, poucas pesquisas são realizadas para obtenção de novas formas de tratamento.

Muitos países hoje considerados isentos desta afecção, como é o caso dos Estados Unidos, Austrália e Japão restringem de maneira agressiva, através de suas barreiras sanitárias, o transporte internacional de animais, ou seja, atualmente é necessário para entrada de eqüinos no território americano, quer seja por exportação temporária ou mesmo definitiva, o exame de ELISA para comprovação de sorologia negativa tanto para a Babesia caballi como para Babesia equi. Neste ponto encontra-se outra problemática bastante séria, já que este teste visa à mensuração dos níveis de imunoglobulinas do tipo G no soro eqüino, e a positividade nesta prova faz com que um animal seja considerado portador e estas imunoglobulinas saidamente, podem permanecer circulantes, por toda vida do eqüino; mesmo que o contato com novos parasitas sejam inibidos. 
Com a somatória de todos estes fatores seria importante o conhecimento de toda a cadeia ou ciclo de vida destes protozoários, quer seja pela sua manutenção na natureza, ou pela relação das diferentes formas de transmissão que podem ocorrer.

A dúvida para realização deste trabalho surgiu em fundamentos e ensaios clínicos que demonstram que mesmo com a inexistência da presença de ixodidiose em determinadas criações a incidência de Babesiose ainda prevalece por longos períodos e que em muitos anos de pesquisas pouco se identificou ou comprovou quanto à existência de transmissão transplacentária da Babesia. 


\section{REVISÃO DE LITERATURA}

\subsection{BABESIA}

A Babesiose eqüina é uma das principais parasitoses dos eqüídeos em conseqüência aos danos diretos e indiretos que pode acarretar na saúde destes animais (FRIEDHOFF, 1988). Trata-se de uma doença causada por protozoários do gênero Babesia transmitidos por carrapatos e que acomete tanto eqüinos como muares e zebras, sendo a única doença parasitária intra-eritrocitária de eqüinos (KERBER, 2004; KNOWLES; UNISS-FLOYD, 1983; MAHONEY, 1977; PURNELL, 1981; REED; BAYLY, 2000).

Esta afecção pode ser causada por dois protozoários intra-eritrocitários sanguíneos distintos: a Babesia caballi e a Babesia equi (Theileria equi), sendo que os eqüídeos podem ser parasitados por uma ou ambas as espécies de babesia concomitantemente (LAVERAN, 1901; NUTTALL; STRICKLAND, 1912, PHIPPS; OTTER, 2004).

A Babesiose é considerada uma doença cosmopolita já que é endêmica em muitas áreas tropicais e subtropicais do mundo, incidindo menos nas zonas de clima temperado, o que corresponde ao habitat dos carrapatos que servem como vetores naturais. Normalmente a Babesia caballi e a Babesia equi estão associadas por utilizarem da mesma espécie de vetores (carrapatos), mas a Babesia equi tem maior prevalência (BRÜNING, 1996; DE WAAL, 1998; REED e BAYLY, 2000; SCHEIN, 1988;). 
As Américas do Sul e Central são consideradas áreas endêmicas, com exceção do sul da Argentina e do Chile. Estudos no Brasil, utilizando o teste sorológico de Fixação de Complemento demonstram um grande número de animais contaminados em todas as áreas testadas, com alta prevalência em regiões de clima marcadamente tropicais ou subtropicais (Minas Gerais, Rio de Janeiro, São Paulo e oeste do Paraná) (KERBER et al., 1999).

A Babesia é o gênero mais importante do grupo babesídeo, pertencente ao filo Protozoa, subfilo Sporozoa e classe Piroplasmidia (FORTES 1987; URQUHART, 1998).

A Taxonomia da Babesia equi tem sido amplamente investigada nos últimos anos por ainda estar incerta. Alguns autores descrevem que a família Piroplasmidae deva incluir a Babesia caballi e o gênero Theileria equi (ao invés de Babesia equi), já que diferente de outras espécies de babesia, esta última inicia seu ciclo dentro de linfócitos antes de parasitar os eritrócitos e divide-se em quatro merozoitos, durante seu ciclo, como algumas espécies de Theileria (BRÜNING, 1996; FORTES 1987; MELHORN e SCHEIN, 1998; URQUHART, 1998).

A Babesia equi tem como sinônimos: Piroplasma equi, Nutallia equi, Nutallia asini, Nutalia minor e Achromaticus equi (LEVINE, 1985). Em concordância aos fatos descritos na nova taxonomia, será admitido neste trabalho a nomina Theileria equi.

A babesiose pode trazer conseqüências graves à saúde dos eqüinos como: anemia, perda de desempenho atlético, abortamento, cólicas ou até óbito; assim como implicações econômicas associadas à doença ou parasitose como: custo do tratamento, alta morbidade ou até mesmo restrições em reunir requerimentos legais para exportação ou participação em provas eqüestres internacionais em países isentos da doença (GUIMARÃES et al., 1997; MARTIN, 1999). 
Após a infecção inicial os animais podem permanecer assintomáticos e manter e carrear um pequeno número de parasitas no organismo, por poucos anos nos casos de Babesia caballi e provavelmente por toda a vida nos casos de Theileria equi (PHIPPS; OTTER, 2004).

\subsection{TRANSMISSÃO}

Sabidamente os dois tipos de babesiose podem ser transmitidos por carrapatos de diferentes espécies nos mais diferentes países do mundo, mas muitos destes vetores naturais ainda não foram conclusivamente definidos como transmissores desta afecção.

Estudos epidemiológicos abordando criações de eqüinos na América do Sul revelam uma elevada intensidade na infestação pelos carrapatos Anocentor nitens (carrapato de orelha), Boophilus microplus (carrapato do boi) e Amblyoma cajennense (carrapato estrela, vermelhinho ou micuim) associados a altos níveis de infecção por babesia (LEITE et al., 1988). No Brasil, o Boophilus tem importância relevante na transmissão da Theileria equi, portanto vem sendo considerado o principal vetor de transmissão. Em relação à Babesia caballi, alguns estudos comprovam a participação do Anocentor nitens no ciclo de transmissão. (CORRÊA et al., 2004; GUIMARÃES et al., 1998; STILLER e COAN, 1995).

Uma característica da Babesiose é que pode ser transmitida por sangue contaminado e por esta razão teria a possibilidade de ser transmitida acidentalmente ou iatrogenicamente. Portanto existe a suspeita de que a infecção por Babesia e Theileria ocorra por fômites contaminados e picadas de insetos hematófagos (GERSTENBERG, 
1998; KNOWLES e UNISS-FLOID, 1983). Segundo Phipps e Otter (2004), apesar da suspeita, os dípteros hematófagos como os tabanídeos e espécies de Stomoxys ainda não são apontados como possíveis vetores de transmissão.

Observações de casos clínicos de babesiose em neonatos sugerem haver transmissão transplacentária da babesia (DONATIEN et al., 1924; GUIMARÃES et al., 1954). Infecções de potros in útero podem ocorrer, resultando no nascimento de potros normais a termo que podem desenvolver os sinais de infecção dias após o nascimento (PHIPPS; OTTER, 2004). Os mesmo autores descreveram em 2004 o primeiro caso de infecção por Theileria equi congênita em um potro na Inglaterra nascido de uma égua importada de Portugal.

\subsection{BABESIA EQUI}

Em 1981 Shein et al. da Universidade de Berlin demonstraram tanto in vivo como in vitro que a Theileria equi desenvolve parte do seu ciclo, formando macro e microesquizontes, dentro de linfócitos e que a invasão dos eritrócitos pelos merozoítos e a esquizogonia intra-eritrocitária só é possível após esta fase intralinfocitária.

Assim sendo quando os esporozoítos são inoculados no hospedeiro (eqüídeo) invadem inicialmente os linfócitos e se desenvolvem ali formando macro e microesquizontes. A partir destes desenvolvem-se então os micromerozoítos que são liberados na circulação sangüínea e penetram nos eritrócitos transformando-se em trofozoítos. Sua multiplicação ocorre por divisão binária ou por esquizogonia. Em geral são formados dois trofozoítos piriformes, inicialmente unidos e depois separados, que destroem os eritrócitos parasitados e ficam livres para penetrarem em outros eritrócitos, 
podendo apresentar-se sob aspecto arredondado, amebóide ou piriforme, quando atingem 2 até $3 \mu \mathrm{m}$ de comprimento (FORTES, 1987). Dificilmente são observados ao microscópio quando a parasitemia é baixa e são facilmente confundidos com artefatos da técnica devido ao seu pequeno tamanho. Durante o ciclo reprodutivo intraeritrocitário eles formam uma espécie de tétrade conhecida como cruz de Malta, uma importante característica deste agente que facilita sua observação microscópica em esfregaços sanguíneos (KERBER, 2004).

Muitos estudos realizados no Brasil afirmam que o Boophilus microplus tem importância relevante na transmissão da Babesia equi, portanto vem sendo considerado como o principal vetor com capacidade de transmissão apesar de ser um parasita monoxeno (de um hospedeiro) e não haver transmissão transovariana entre as gerações, o que restringe a transmissão de um animal a outro como ocasional (CORRÊA et al., 2004).

O ciclo biológico do Boophilus microplus, apresenta 1 fase de 21 dias na qual passa pelos estágios de larva, ninfa e adulto, todos em um único hospedeiro. A fase de vida livre inicia-se com a queda das fêmeas ingurgitadas e culmina quando as larvas eclodidas encontram o hospedeiro. Na fase de vida livre, a fêmea ingurgitada apresenta um período de pré-postura de três dias, morrendo após a postura. Em temperatura ao redor de $28^{\circ} \mathrm{C}$ e umidade relativa em torno de $85 \%$, a postura e eclosão dos ovos ocorrem em aproximadamente 18 dias. As larvas recém eclodidas migram para os pontos vegetais aonde possam localizar o hospedeiro pelo odor ou vibrações, geralmente na extremidade de gramíneas de folha larga. No hospedeiro as larvas se fixam em regiões corpóreas propícias para seu desenvolvimento, como: região posterior da coxa, perineal, perivulvar, cola da cauda e após sete dias da fixação ocorre 
a muda para ninfa e esta realiza muda para adulto com marcado dimorfismo sexual em torno de oito dias. As fêmeas após acasalamento começam alimentação até ingurgitamento total, que propicia sua queda ao solo, enquanto o macho permanece no hospedeiro à procura de novas fêmeas (MASUDA et al., 2004).

Já o Amblyomma cajennense é um carrapato trioxeno, ou seja, necessita de três hospedeiros de espécies iguais ou diferentes para completar seu ciclo de vida. Após eclosão dos ovos sobe ao hospedeiro para o repasto de linfa ou sangue e tecidos, diferido como larva cai ao solo buscando esconderijo em rachaduras do solo ou touceiras de capim, depois se fixa como ninfa em um segundo hospedeiro, vai ao solo e finalmente, encontrando o terceiro hospedeiro inicia novo repasto sanguíneo já como macho ou fêmea jovem. A fêmea é fertilizada e inicia o processo de ingurgitamento que dura aproximadamente dez dias. Após este período ela se solta e vai ao solo iniciando uma nova geração com a deposição de aproximadamente 5000 ovos. Dessa formal, mesmo que não seja possível a transmissão transovariana, um ácaro que se infecte em uma fase da vida, pode transmitir a babesia em outra fase da vida, fato denominado transmissão transestadial. De fato estudos realizados por Kerber et al. (1999) demonstraram que há forte correlação entre a presença deste carrapato e animais soropositivos para Theileria equi.

Na transmissão da Babesia transestadial, os parasitos ingeridos por ocasião do repasto sanguíneo, não se multiplicam no epitélio intestinal e, ao atingirem a hemocele, reproduzem-se por divisão múltipla, originando os pseudocistos com 14 até $35 \mu \mathrm{m}$ de diâmetro. Os pseudocistos rompem-se e os parasitos liberados, medindo de 2 até $3 \mu \mathrm{m}$ de diâmetro, invadem músculos e multiplicam-se nestes, por diversas divisões binárias, constituindo um grande número de parasitos medindo de 9 até $12 \mu \mathrm{m}$ de comprimento. 
Os músculos do carrapato permanecem inalterados durante suas metamorfoses. Quando o estádio posterior inicia sua alimentação no hospedeiro, os parasitos migram até as glândulas salivares e, penetrando nas suas células, reproduzem-se por repetidas divisões binárias, originando um grande número de estádios infectantes com $1 \mu \mathrm{m}$ de comprimento, que serão transmitidos ao hospedeiro vertebrado (FORTES, 1987).

Devido a algumas características da Babesia equi como seu ciclo extraeritrocitário, seu tamanho reduzido e ausência da transmissão transovariana, a sua classificação taxonômica permanece incerta, como anteriormente relatado. Alguns autores, como Melhorn e Schein (1998), afirmam que entre os eqüinos a Babesia equi foi classificada como sendo do gênero Theileria, que, no entanto, não tem ciclo eritrocitário. Análises comparativas com técnicas de biologia molecular indicam que a Babesia equi deve ser caracterizada como um grupo distinto (KERBER, 2004).

A descrição literária de casos isolados de neonatos portadores de Theileria equi ou mesmo de natimortos ou abortamentos, caracteriza a possibilidade de transmissão transplacentária nas éguas ao final da gestação, fato que se comprovado poderia esclarecer melhor a grande prevalência desta afecção em muitas regiões consideradas endêmicas no Brasil.

\subsection{BABESIA CABALLI}

É uma Babesia típica que invade exclusivamente os eritrócitos, nos quais os esporozoítos inoculados se transformam em trofozoítos que crescem e dividem-se em dois merozoítos em forma de pêra com 2 até $5 \mu \mathrm{m}$ de comprimento unidos na sua parte posterior, que podem destruir a célula parasitada para invadirem outras duas novas 
células. Após ingestão das Babesias pelas fêmeas dos carrapatos ocorre penetração e multiplicação nas células epiteliais intestinais tomando então a forma de clava. Após esta fase elas chegam à hemocele, havendo penetração e multiplicação nas células dos tubos de Malpighi, nos ovários e penetração nos oócitos, conseqüentemente infecção nas glândulas salivares, multiplicando-se nos ácinos destas glândulas e podendo ser transmitidas ao vertebrado por ocasião da sucção de sangue pelo carrapato (FORTES, 1987; KERBER, 2004).

Em relação à Babesia caballi, alguns estudos comprovam a participação do Anocentor nitens no ciclo de transmissão (CORRÊA et al., 2004).

O Anocentor nitens é um importante ectoparasito de eqüinos desde o sul dos EUA até o norte da Argentina. No Brasil é encontrado parasitando cavalos e outros eqüídeos, sendo responsável por muitas doenças incluindo lesões na orelha, em conseqüência da perda da rigidez auricular por quebra do tecido cartilagíneo (OLIVEIRA, 2004). Este é um carrapato de um só hospedeiro, ou seja, monoxeno. As transformações de larva a adulto ocorrem na orelha do hospedeiro. Os adultos iniciam a cópula aproximadamente dois dias após sua transformação e permanecem em coito até a queda da fêmea. Essa retorna ao hospedeiro, ingurgita em aproximadamente 9 a 23 dias, iniciando a postura 3 a 15 dias após a queda (FLECHTMANN, 1985).

As fêmeas realizam a postura, de forma a deixarem os ovos aglutinados. Terminada a ovoposição as fêmeas morrem. Os ovos são pequenos, esféricos e de coloração castanha. Os ovos eclodem e dão origem às larvas. Caso haja condições climáticas favoráveis, estas larvas sobem pelas gramíneas e arbustos e aí esperam a passagem dos hospedeiros para os quais se transferem (OLIVEIRA, 2004). 
No ciclo evolutivo da Babesia caballi, o carrapato adulto infecta-se, mas não transmite a doença, o que será feito pela geração seguinte. A transmissão ocorre de geração a geração pela passagem transovariana, ou seja, do carrapato fêmea aos seus descendentes, podendo manter-se por até quatro gerações, o que faz destes ácaros o reservatório da doença na natureza (FORTES, 1987).

\subsection{PATOGENIA}

Tanto a Babesia caballi como a Theileria equi, após sua passagem pelos linfócitos, multiplicam-se e desenvolvem-se dentro dos eritrócitos do hospedeiro. Muitos destes eritrócitos parasitados podem se romper ocasionando uma intensa hemólise intravascular ou ainda podem ser removidos da circulação pelo sistema mononuclear fagocitário. A doença decorrente destas alterações pode ser muito mais grave no caso de infestações agudas por Theileria equi do que pela Babesia caballi, fato que pode ser notado no maior índice de mortalidade causado pela primeira. (REED; BAYLY, 1998).

Acredita-se que potros nascidos em áreas endêmicas possam apresentar infecção assintomática e à medida que perdem os anticorpos maternos passivos ingeridos no colostro poderiam desenvolver forte imunidade ativa, que logicamente depende da presença constante dos protozoários. Fatores estressantes como treinamento, transporte, condições climáticas adversas ou qualquer outra doença concomitante pode induzir a manifestação clínica e oportunista em eqüinos portadores dos microorganismos (REED; BAYLY, 1998).

A doença caracteriza-se por febre, anemia, depressão, ataxia, anorexia, fraqueza, epífora, secreção nasal mucóide, edema, icterícia e hemoglobinúria, 
ocorrendo tipicamente uma ou duas semanas depois que os carrapatos parasitam e contaminam o hospedeiro (KNOWLES, 1980; REED; BAYLY, 1998; ZAUGG, 1990). Pode ocorrer morte em 48 horas ou a doença se transformar em forma crônica (febre e anemia) que pode persistir por meses. Eqüinos criados em áreas endêmicas costumam ser portadores de Babesia sem exibir sinais clínicos (REED; BAYLY, 1998).

Segundo Allsopp (1994), após o período de infecção e incubação, que pode ser de 10 a 30 dias nos casos de Babesia caballi e de 12 a 19 dias nos casos de Theileria equi, o primeiro sinal clínico na fase aguda é marcado pelo aumento da temperatura, associado ao aparecimento do parasito na corrente sanguínea. A anemia é causada pela diminuição no número de eritrócitos por lise, havendo liberação de hemoglobina e depósito da bilirrubina nos tecidos, o que produz a icterícia. Parte da hemoglobina é eliminada na urina, ocasionando a hemoglobinúria. Poderá ainda ocorrer à obstrução de capilares dos órgãos viscerais pelas hemácias parasitadas, parasitos e detritos celulares, sendo que a associação destes fatores produz metabólitos tóxicos e anóxia que poderão levar o animal a morte.

A parasitemia, no caso da Babesia caballi pode chegar a $1 \%$ das células, da linhagem vermelha e dificilmente o animal morre de anemia, mas principalmente pela formação de microtrombos. No caso da Theileria equi a parasitemia é maior, comumente por volta de $7 \%$ dos eritrócitos, mas em animais imunodeprimidos ou sem qualquer contato prévio que lhes garanta imunidade, a parasitemia pode chegar a $80 \%$ e a morte se dá por anemia aguda (KERBER et al., 1999).

A doença clínica associada à infecção por Theileria equi é muito mais grave que a causada por Babesia caballi, e a taxa de mortalidade é mais elevada, como já relatado. Acredita-se que potros nascidos em áreas endêmicas apresentarão a infecção 
assintomática à medida que perdem os anticorpos maternos e, assim desenvolverão forte imunidade ativa, que depende da presença constante do microorganismo. Estresses como treinamento, transporte, condições climáticas adversas ou prenhez podem induzir a doença clínica em eqüinos portadores do microorganismo (REED; BAYLY, 2000).

Os animais infectados por Theileria equi persistem infectados por anos, provavelmente durante toda a vida, enquanto que infecções causadas por Babesia caballi não são persistentes e são pouco estáveis no organismo integro e que produza altos níveis de anticorpos (ALMEIDA, 2001). A maioria dos eqüinos infectados reage fortemente ao estímulo antigênico da presença da babesiose produzindo anticorpos tanto do tipo IgG como IgM (EUZEBY et al., 1980).

A maioria dos protozoários é altamente antigênica, mas em sua adaptação evolutiva desenvolveram mecanismos de proteção através dos quais podem sobreviver na presença de uma resposta imune intensa, como por exemplo, abrigarem-se dentro dos eritrócitos. Portanto, como outros microorganismos, os protozoários estimulam tanto as respostas imune humorais como as mediadas por células. De maneira geral, os anticorpos controlam, ou tentam controlar, os níveis de parasitas na corrente sanguínea e nos fluídos teciduais, enquanto as respostas mediadas por células se direcionam mais especificamente contra os parasitas que estão no espaço intracelular. $\mathrm{Na}$ Babesiose, os estágios infectantes do microorganismo (esporozoítos) invadem as hemáceas, essa invasão aparentemente envolve a ativação do sistema complemento alternativo. As hemáceas parasitadas incorporam os antígenos da Babesia em suas membranas. Estes antígenos de membrana por sua vez induzem anticorpos que opsonizam as hemáceas e levam a sua remoção da circulação pelo sistema 
mononuclear fagocitário. Além da resposta humoral, a resposta mediada por células anticorpo dependentes também pode destruir as hemáceas infectadas, assim como o complexo antígeno anticorpo. (TIZARD, 1998)

\subsection{DIAGNÓSTICO}

Um importante relatório técnico científico foi amplamente divulgado nos meses que antecederam os jogos Olímpicos de Sydney em 2000. Neste relatório o serviço responsável pela inspeção e quarentena dos animais alertou quanto ao importante risco para o país, na importação temporária de eqüinos soropositivos para Babesia. Muitas propostas para medidas de controle dos riscos e necessidade de quarentenário, além da ênfase na proibição da entrada de animais positivos naquele país foram relatadas (MARTIN, 1999). Medidas como estas somente voltam a enfatizar a importância no desenvolvimento de métodos de diagnóstico da Babesia nas suas diferentes apresentações (BRÜNING, 1996).

O diagnóstico definitivo de Babesiose baseia-se na demonstração de eritrócitos parasitados em esfregaços sanguíneos ou na sorologia positiva. Como a parasitemia é de curta duração e em geral não há hemólise, é mais comum estabelecer-se o diagnóstico pela sorologia, uma vez que mesmo doentes muitos animais demonstram esfregaço sanguíneo negativo. Os anticorpos contra Babesia são detectáveis após 14 dias da infecção por um teste de fixação do complemento ou imunofluorescência indireta (KNOWLES, 1980; ZAUGG, 1990). Dificilmente o agente é observado ao microscópio quando a parasitemia é baixa e são facilmente confundidos com artefatos da técnica devido ao seu pequeno tamanho. Durante o ciclo reprodutivo intra- 
eritrocitário, formam uma tétrade conhecida como cruz de Malta, uma importante característica para o diagnóstico deste agente (JAIN, 1993; KERBER, 1999).

Portanto o diagnóstico definitivo da Babesiose pode ser subdividido em técnicas diretas ou indiretas. O método direto se dá por meio da visualização dos protozoários em esfregaços de sangue ou pela investigação do DNA, por diferentes técnicas de PCR (Polimerase Chain reaction). Já as técnicas indiretas são realizadas por meio das mensurações das respostas imunológicas, ou seja anticorpos, através do exame sorológico, como o Teste de Fixação de Complemento (TFC), o Teste de Imunofluorescência de anticorpos (TIF) e o teste de ELISA (Enzime linked immunosorbent assay) (DE WALL et al., 1987; KUTTLER et al., 1988; MERKLE, 1983; POSNETT et al., 1991).

Desde setembro de 2005 o método oficial para que se obtenha a permissão de transporte internacional e eqüinos para os países isentos da doença, segundo a OIE, é o teste de cELISA (ELISA competitivo), se sobrepondo ao antigo teste de Fixação de complemento, ambos para detecção de anticorpos contra Babesia caballi e Theileria equi. O teste de Fixação de complemento, ainda requerido para permissão de entrada em poucos países foi desenvolvido por Hirato e sua equipe em 1945, e desde 1969 vinha sendo utilizado pelo Departamento Americano de Agricultura como teste oficial na importação de eqüinos (FRIEDHOFF, 1982).

A observação dos sinais clínicos já descritos conjuntamente com a demonstração da Babesia ou Theileria em esfregaços sanguíneos corados são suficientes para o diagnóstico definitivo. Mas em conseqüência das dificuldades de detecção de números baixos de parasitas pela microscopia, métodos sorológicos como o Teste de Fixação de Complemento que detecta principalmente IgM assim como o 
cELISA que baseia-se na detecção de IgG têm sido utilizados como métodos de auxílio ao diagnóstico (BÖSE, et al., 1995; PHIPPS; OTTER, 2004).

O exame direto ao microscópio como técnica de diagnóstico pode ser bastante útil principalmente nos casos agudos da doença quando há alta parasitemia, sendo possível encontrar facilmente os parasitas dentro das hemáceas. Diferentemente nos casos subagudos ou crônicos, onde a parasitemia possa ser mais baixa é muito difícil encontrar tanto a Theileria equi como a Babesia caballi, assim como podem ser confundidos facilmente com artefatos de técnica, de tal forma que a resultados falso positivos ou falso negativos são comuns pela diminuição da sensibilidade do teste ou mesmo da falta de prática do examinador (KERBER, 2004).

Os anticorpos contra a Theileria equi assim como contra a Babesia caballi são detectáveis em média 14 dias após a infecção inicial pelo teste de Fixação de complemento, portanto mesmo este teste sorológico pode apresentar falsos negativos quando da fase aguda da infecção (KNOWLES, 1980; REED; BAYLY, 1998; ZAUGG, 1990).

Alguns trabalhos demonstram que o esfregaço sanguíneo pode detectar cerca de $32 \%$ dos animais infectados pela Babesia, já técnicas sanguíneas de detecção de protozoário como o PCR em tempo real, nas mesmas amostras podem detectar uma porcentagem maior de animais infectados pela Theileira equi ou mesmo Babesia caballi (BATTSETSEG et al., 2001; RAMPERSAD et al., 2003).

Apesar da altíssima sensibilidade demonstrada pelo teste de PCR, os portadores crônicos têm apresentado resultados falso negativos, sendo a provável explicação que nesta fase talvez de haver poucos parasitas circulantes, de tal forma 
que não haja DNA dos protozoários disponível na amostra sangüínea coletada (KERBER, 2004).

Os principais exames laboratoriais utilizados no diagnóstico ou como auxiliar ao diagnóstico na Babesiose eqüina são:

\subsubsection{Esfregaço sanguíneo}

O esfregaço sanguíneo é realizado estendendo-se uma pequena gota de sangue sobre uma lâmina, formando uma fina película de sangue que deve ser corada e examinada ao microscópio óptico. Para este procedimento é necessário que o sangue seja colhido em tubo com anticoagulante, de onde se retira uma pequena gota com auxílio de um microcapilar de hematócrito. Os corantes mais utilizados para coloração do esfregaço e realização da pesquisa de hematozoários são o Giemsa e o corante de Wright. O método para corar a lâmina preparada consiste em cobrir a mesma com o corante de escolha por 3 a 5 minutos, cobrir o corante com água destilada por 10 minutos e posteriormente lavar a lâmina com água abundante (BATTSETSEG et al., 2002; NAVARRO; PACHALY, 1994).

\subsubsection{Teste de Fixação de Complemento (TFC)}

Entre os testes sorológicos atualmente utilizados para o diagnóstico da Babesiose, o teste de Fixação de Complemento é o mais aceito na maioria dos países. Embora seja uma técnica bastante minuciosa e trabalhosa é de fácil padronização e tem boa sensibilidade, sendo o teste mais utilizado para diagnóstico no trânsito 
internacional de eqüinos na última década (KERBER, 2004). A exportação de cavalos para os Estados Unidos, Canadá, Austrália e Japão é restrita aos animais soronegativos para o teste de Fixação de Complemento (TAULOR et al., 1969; WEILAND, 1986).

O teste de Fixação de Complemento para pesquisa de Babesia tem sido visto como qualitativo, mas pode ser interpretado quantitativamente. O primeiro baseia-se na titulação do complemento residual que não foi consumido pela reação antígenosanticorpo com o sistema preparado para indicar a reação. Já o método quantitativo possui muitas variações técnicas que permitem revelar as quantidades mínimas de complemento fixado (FERREIRA, 1996).

Este teste de Fixação de Complemento para Babesia, pesquisa sorologicamente o nível de anticorpos circulantes, o que não implica na presença da doença propriamente dita, tanto pelos achados de anticorpos contra Babesia caballi como da Theileria equi (CORRÊA et al., 2004). Segundo Hirato et al. (1945) os anticorpos contra Babesia caballi são observados pelo teste de Fixação de Complemento de 11 a 15 dias após a primeira parasitemia. Mas mesmo após eliminação da Babesia caballi os animais podem apresentar positividade no TFC por aproximadamente 3 a 15 meses, apesar dos anticorpos como IgM permanecerem por períodos inferiores na circulação. Portanto é considerado um teste altamente eficaz na determinação de animais que ao menos tiveram contato com este agente (HOURRIGAN e KNOWLES, 1979; STEPANOVA e PETROVSKII , 1975). 


\subsubsection{Ensaio imunoenzimático (ELISA)}

O princípio básico deste teste desenvolvido como alternativo ao radioimunoensaio para detecção de antígenos e anticorpos é a imobilização de um dos reagentes em uma fase sólida, enquanto outro reagente pode se ligar a uma enzima, com preservação tanto da atividade enzimática como da imunológica, neste caso do anticorpo. Desde que a técnica seja adequadamente padronizada pode ter elevada sensibilidade e especificidade, portanto é um teste que pode detectar quantidades extremamente pequenas de antígenos ou anticorpos dependendo do tipo de teste desejado. Um dos fatores importantes na realização do teste é o grau de pureza do antígeno ou do anticorpo na fase sólida, pois quaisquer alterações no material heterólogo podem resultar em falsos positivos ou negativos (FERREIRA, 1996).

A alta sensibilidade do teste de ELISA é uma vantagem neste exame laboratorial para pesquisa de Babesia. Esta qualidade faz com que este seja um ensaio amplamente empregado na detecção de antígenos e anticorpos bem como na quantificação de anticorpos produzidos em diversas doenças bacterianas, fúngicas e virais (BIER et al., 1989; VAZ; CALICH, 2001).

A realização de diagnóstico de infecção por Babesia em várias espécies, através da técnica do ensaio imunoenzimático, tem sido descrita como, por exemplo, em bovinos para Babesia bovis, Babesia divergens e Babesia major, assim como em cães para Babesia canis e Babesia gibsoni (BARRY et al.,1982; KRATZER, 1979; PURNELL et al., 1976; WEILAND; KRATZER, 1979; YOUNG; PURNELL, 1980).

Mesmo que o teste de ELISA venha se mostrando tão sensível quanto o teste de Fixação de Complemento na pesquisa de animais soropositivos para Babesiose, sua 
especificidade é questionável. Alguns trabalhos com animais positivos para Theileria equi utilizando a reação cruzada com antígenos de Babesia caballi e Babesia rodhaine mostram que apesar da alta sensibilidade este exame não é muito específico, em função da irregularidade nos resultados encontrados (BÖSE; PEYMANN, 1994; GÖTZ, 1982).

\subsubsection{Reação em cadeia da Polimerase (PCR)}

O PCR é uma técnica laboratorial que reproduz artificialmente a forma como o DNA é replicado na natureza. A técnica de PCR tem sido utilizada com os mais diferentes propósitos que vão desde a identificação de indivíduos a partir de fragmentos, análise de DNA pré-histórico, diagnóstico de doenças, auxilio em investigações policiais, determinações de paternidade, entre outras aplicações. O PCR é um método rápido e versátil para a amplificação de segmentos de DNA e pode ser implementado a partir de uma molécula. Usualmente, o método é realizado de forma a permitir uma amplificação seletiva de uma seqüência alvo específica dentro de uma coleção heterogênea de DNA. A técnica de PCR é uma reação em cadeia porque o DNA sintetizado em ciclo inicial passa a ser o molde para a síntese posterior de DNA nos ciclos subseqüentes. A reação envolve ciclos seqüenciais completos compreendendo: a desnaturação e a dissociação das ligações da fita dupla de DNA, o realinhamento e a síntese de uma nova seqüência complementar de DNA (OLIVEIRA; HENKES, 2002). 
O teste de PCR consiste de três grandes fases: desnaturação, pareamento e extensão. Segundo Silva e Cabral (1997) os principais eventos moleculares que ocorrem em cada uma destas etapas são:

Desnaturação: nesta fase, o calor é utilizado para paralisar todas as atividades enzimáticas e desnaturar o DNA de dupla fita em fita simples. Normalmente a temperatura de $94^{\circ} \mathrm{C}$ é utilizada, mas alguns novos protocolos têm utilizado temperaturas um pouco menores. Quanto mais baixas as temperaturas ou quanto mais curta a fase de desnaturação, maior o índice de falha em dissociar completamente o DNA genômico de alto peso molecular.

Pareamento: nesta fase a temperatura é diminuída para que os oligonucleotídeos inicializadores possam ligar-se aos sítios apropriados no DNA molde. Esta é a fase crítica, pois se os "primers" ligam-se corretamente somente às posições alvo molde, há então uma possibilidade de que a síntese produza algum produto, entretanto muitos fatores podem atrapalhar esta ação. O pareamento é um processo randômico que depende da concentração dos oligonucleotídeos, da disponibilidade de sítios de pareamento e da presença de posições de pareamento não ideais, que competem com os sítios ideais de pareamento.

Extensão: nesta fase a enzima polimerase trabalha sintetizando o segmento de DNA. Normalmente a temperatura utilizada para esta fase é de cerca de $72^{\circ} \mathrm{C}$, assim como o tempo de extensão também é importante, já que milhares de bases podem ser sintetizadas por minuto de reação. Normalmente 30 segundos são utilizados para esta reação já que este tempo é suficiente para produzir 500 pares de bases, assim como se utilizado 60 segundos um total de 1500 bases podem ser produzidas. 
O PCR é extremamente eficiente para diagnósticos de Theileria equi já que se trata de um exame altamente específico, entretanto, em animais que não apresentam sintomas da doença, portanto possuem níveis baixos da infecção, os resultados obtidos podem ser falso-negativos, sendo necessário para estes animais outros exames, como o exame do esfregaço sanguíneo ou mesmo o Teste de Fixação de Complemento (BAHIRUDDIN et al., 1999; RAMPERSAD et al., 2003).

O PCR veio trazer velocidade, sensibilidade e maior especificidade às técnicas de detecção de microorganismos, já que pequenas quantidades de DNA e/ou RNA presentes numa amostra (1 ng de ácido nucléico ou menos) podem ser repetidamente amplificados e detectados (PRICHARD, 1997).

Considerando a Babesiose uma importante afecção da equideocultura mundial, que limita consideravelmente o trânsito internacional de animais, tanto para competições como para exportação e importação, muito se estuda quanto ao delineamento cada vez mais preciso de técnicas eficazes de diagnóstico, mesmo que a grande maioria destas técnicas não comprove a existência da doença nos indivíduos estudados, mas apenas o contato prévio aos quais eles possam ter sido submetidos.

Além disso, o estudo da cadeia de transmissão tanto da Theileria equi como da Babesia caballi tem sido um alvo de diferentes investigações a fim de auxiliar não só o tratamento como o controle desta afecção de proporções perturbadoras tanto no Brasil como em muitos outros países.

Nenhum trabalho até o momento objetivou a documentação ou comprovação da possibilidade de transmissão transplacentária da Babesia, fato que pode ser entendido pela inadequação das técnicas diagnósticas que pesquisam anticorpos e que 
não podem ser utilizadas em neonatos eqüinos com poucos dias de vida, já que estes não apresentariam níveis identificáveis, como é o caso dos testes de Fixação de Complemento ou mesmo o ELISA. 


\section{OBJETIVOS}

Portanto o objetivo principal deste trabalho foi avaliar a ocorrência de transmissão transplacentária da Theileria equi através da avaliação sanguínea de éguas Puro Sangue Lusitano e de seus potros nas primeiras horas de vida, com a utilização do teste de RT-PCR. 


\section{MATERIAL E MÉTODOS}

\subsection{ANIMAIS UTILIZADOS}

A avaliação hematológica foi realizada pela colheita de amostras de sangue periférico da veia jugular de 100 eqüinos, dos quais, 50 neonatos, machos e fêmeas, nas primeiras horas de vida, não ultrapassando 5 horas do nascimento; além das 50 mães no mesmo momento da colheita dos neonatos.

Os referidos animais eram da raça Puro Sangue Lusitano e encontravam-se alojados em propriedade de criação (haras), localizada no município de Itirapina - São Paulo, mantidos em condições padrão de criação e considerados sadios ao exame clínico no momento da colheita. O exame físico baseou-se na avaliação de freqüência cardíaca, freqüência respiratória, coloração de mucosas oculares e orais, temperatura corpórea, além de auscultação pulmonar e observação do estado corpóreo e das condições de pele, pêlo e anexos.

Na propriedade em questão todos os animais são vacinados anualmente contra tétano, encefalomielite eqüina e inlfuenza (Fluvac EWT®), Herpes vírus (Fluvac EHV 4/1®) e Raiva (BGS-CELL®), além de serem a cada 2 ou 3 meses vermifugados com produtos a base de Ivermectina isolada ou associada com Palmoato de Pirantel.

Todas as éguas são criadas em região endêmica para Babesiose, principalmente pela grande presença de carrapatos vetores na região do haras escolhido, apesar do controle período ectoparasitário através de banhos individuais com bomba costal e produto à base de Deltametrina (Butox $®)$. 


\subsection{COLHEITA DE SANGUE E PREPARO DAS AMOSTRAS}

Cada amostra de sangue, tanto das éguas como dos potros, num volume de $5 \mathrm{~mL}$, foi colhida após assepsia local, por punção da veia jugular, utilizando frasco limpo com anticoagulante (vacutainer $\left.{ }^{\circledR}\right)$ e imediatamente congelado em freezer a $-20^{\circ} \mathrm{C}$. Periodicamente eram transportados congelados ao laboratório para realização das provas de RT-PCR.

Todas as éguas tiveram soro colhido no mesmo dia da colheita de sangue total, acondicionados em frasco limpo sem anticoagulante (vacutainer®) num volume total de $5 \mathrm{~mL}$, as quais eram deixadas em temperatura ambiente até a coagulação e retração do coágulo, para em seguida ser centrifugado a $3.000 \mathrm{rpm}$, durante cinco minutos, para melhor separação do soro. O soro era transferido, com auxílio de uma pipeta de Pasteur para frasco apropriado e congelado imediatamente na temperatura de $-20^{\circ} \mathrm{C}$. Periodicamente eram transportados ao laboratório para realização da técnica de CELISA.

A colheita do material deu-se de forma aleatória de acordo com os dias de parto das 50 éguas do experimento. A colheita de sangue dos neonatos era realizada neste mesmo dia.

\subsection{TESTE DE RT-PCR}

O teste de RT-PCR consiste de várias etapas, as quais podem ser resumidas como na descrição a seguir: 


\subsubsection{Isolamento e precipitação do DNA}

A técnica de isolamento de T. equi e B. caballi foi adaptada da técnica proposta por Hitoshi et al. (2001). Resumidamente, de cada amostra $200 \mu$ le sangue foram colocados em um microtubo $(1,5 \mathrm{~mL})$ e adicionado $500 \mu \mathrm{l}$ de tampão Tris-EDTA (50nM Tris, $\mathrm{pH}=8,0 ; 100 \mathrm{nM}$ EDTA) contendo $0,5 \%$ de SDS e $30 \mu \mathrm{l}$ d proteinase $\mathrm{K}(10 \mathrm{mg} / \mathrm{mL})$.

Os tubos foram incubados a $42^{\circ} \mathrm{C}$ durante 12 horas. Após este período foram adicionados $500 \mu \mathrm{l}$ de uma solução contendo fenol, clorofórmio e álcool isoamílico e centrifugados por 3 minutos a 12000 x g, sendo este procedimento repetido duas vezes.

Para a precipitação do DNA a fase aquosa foi transferida $(400 \mu \mathrm{l})$ para outro microtubo e adicionados $40 \mu \mathrm{l}$ de $3 \mathrm{M}$ de acetato de sódio $(\mathrm{pH}=6,0)$ e 1,0 $\mathrm{mL}$ de etanol absoluto gelado. O precipitado de DNA formado foi aspirado e transferido para um novo microtubo. O DNA foi lavado com $1,0 \mathrm{~mL}$ de etanol a $70 \%$ sob agitação e deixado para secar em estufa a $37^{\circ} \mathrm{C}$ por pelo menos 15 minutos. O DNA foi dissolvido em $100 \mu \mathrm{l}$ de água estéril.

\subsubsection{Técnica de detecção de T. equi e B. caballi}

Para a detecção dos hematozoários foi realizada a técnica de RT-PCR utilizando o Kit de detecção baseado no fluoróforo intercalante de DNA SYBERGreen, segundo instruções do fabricante (Applied Biosystems). A detecção foi mensurada utilizando-se um equipamento de PCR em tempo real (RT-PCR) (modelo ABI7300 Sequence Detection System, Applied Biosystems,CA). Para a verificação da presença de dímeros 
de oligonucleotídeos de cada amostra foi realizada a curva de dissociação ao final dos ciclos de amplificação e, caso fosse observada a presença destes, a reação foi repetida. Por meio da análise das seqüências disponíveis no banco de dados público norte americano (NCBI) foram alinhadas as seqüências do gene ribossomal $18 \mathrm{~S}$ de diferentes espécies de babesias. Os oligonucleotídeos específicos para T. equi e B. caballi foram desenhados em regiões não compartilhadas. As seqüências estão representadas no quadro 1.

Quadro 1 - Seqüência dos oligonucleotídeos utilizados no ensaio de RT-PCR para detecção de T. equi e B. caballi - São Paulo, 2006

\begin{tabular}{ccc}
\hline Espécie & forward & Reverse \\
\hline Theileria equi & gggaatctaaacccttcca & taatagaaacccaaccaagc \\
\hline Babesia caballi & acccatcagcttgacggtcg & gagggtttaagtcgccatca \\
\hline
\end{tabular}

Componentes do Kit SYBR Green

250 U AmpliTaq Gold ${ }^{\circledR}$ DNA Polymerase $(50 \mu l)$

100 U AmpErase ${ }^{\circledR}$ UNG $(100 \mu \mathrm{l})$

dNTP Mix with dUTP $(1 \mathrm{~mL})$

10X SYBR ${ }^{\circledR}$ Green PCR Buffer $(1.5 \mathrm{~mL})$

$25 \mathrm{mM} \mathrm{MgCl} 2$ Solution $(3.0 \mathrm{~mL})$.

\subsection{TESTE DE cELISA}

Com o conhecimento da possibilidade de resultados falso negativos como descrito por Rampersad et al. (2003), foi proposto que as éguas negativas para 
Theileria equi, com potros positivos, fossem testadas pela técnica de cELISA. Portanto após realização dos exames de RT-PCR das 50 éguas foram selecionadas as amostras de soro previamente congeladas para realização do teste de cELISA no laboratório Equallis no Jockey Clube de São Paulo. 


\section{ANÁLISE ESTATÍSTICA}

Os resultados encontrados foram apresentados diretamente por sua distribuição porcentual seguindo os valores qualitativos entre positivos e negativos e suas relações entre éguas e potros.

Além disso, utilizou-se o teste de Qui-quadrado para avaliação das associações existentes nas distribuições encontradas entre éguas e potros considerando $\alpha=0,05$.

As análises foram processadas com o auxílio do programa estatístico computadorizado Minitab, versão 13.0 (licenciado para a USP, 2000). 


\section{RESULTADOS}

Os resultados dos testes de RT-PCR realizados nas 100 amostras colhidas, sendo 50 potros e suas mães, tanto para Theileria equi como para Babesia caballi estão apresentados respectivamente nas tabelas 1 e 2 e de forma individualizada no apêndice - A.

Tabela 1 - Resultado de RT-PCR para Theileira equi nas éguas e potros ao primeiro dia de nascimento - São Paulo - 2006

\begin{tabular}{cccc}
\hline Theileria equi & Potros positivos & Potros negativos & Total \\
\hline Éguas positivas & 17 & 6 & 23 \\
Éguas negativas & 16 & 11 & 27 \\
\hline Total & $\mathbf{3 3}$ & $\mathbf{1 7}$ & $\mathbf{5 0}$ \\
\hline
\end{tabular}

Tabela 2 - Resultado de RT-PCR para Babesia caballi nas éguas e potros ao primeiro dia de nascimento - São Paulo - 2006

\begin{tabular}{cccc}
\hline Babesia caballi & Potros positivos & Potros negativos & Total \\
\hline Éguas positivas & 1 & 7 & 8 \\
Éguas negativas & 0 & 42 & 42 \\
\hline Total & 1 & 49 & 50 \\
\hline
\end{tabular}


Os resultados do teste de RT-PCR para Theileria equi demonstraram que 23 (46\%) das éguas apresentaram resultado positivo e 27 (54\%) se mostraram negativas, enquanto que $33(66 \%)$ potros apresentaram resultados positivos sendo que destes 17 (34\% do total) eram produtos de mães também positivas no dia do parto e outros 16 (32\% do total) produtos de mães negativas no mesmo dia, enquanto que 17 (34\%) potros apresentaram resultados negativos sendo que destes, $11(22 \%$ do total) eram produtos de mães também negativas e 6 (12\% do total) produtos de mães positivas, como apresentado nos gráficos - 1 e 2 .

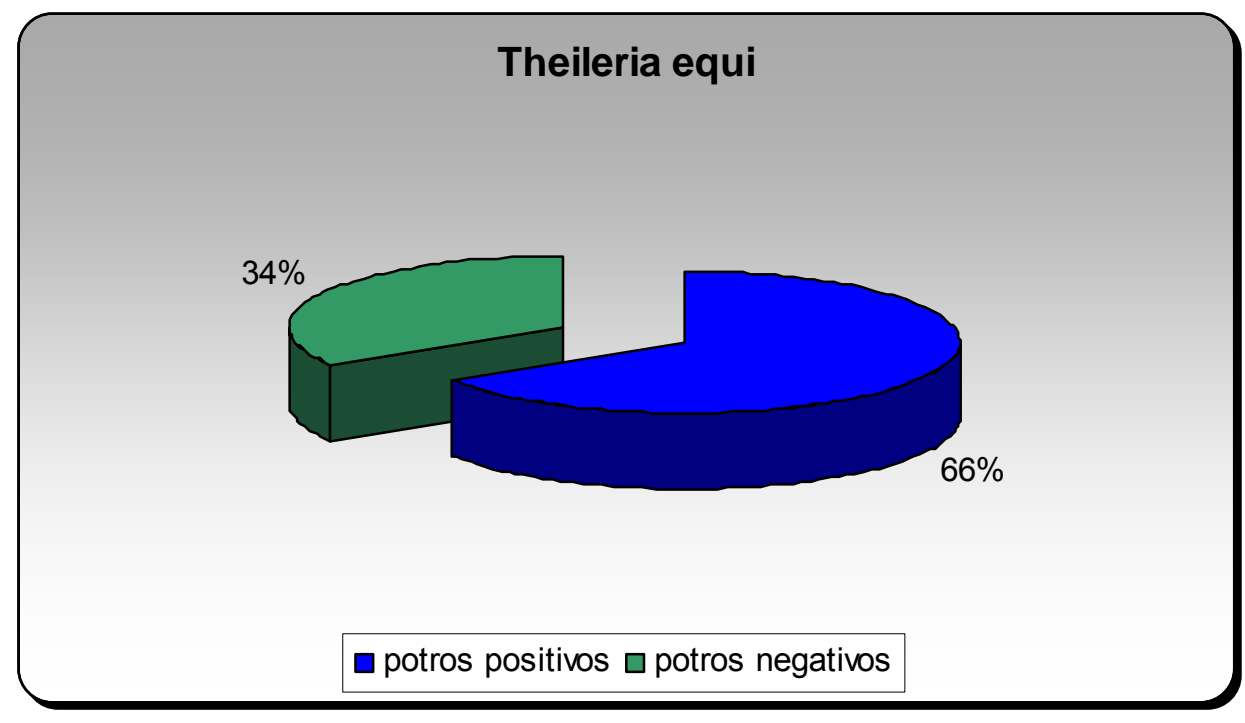

Gráfico 1 - Representação da porcentagem de potros nascidos positivos para Theileria equi no teste de RT-PCR São Paulo - 2006 


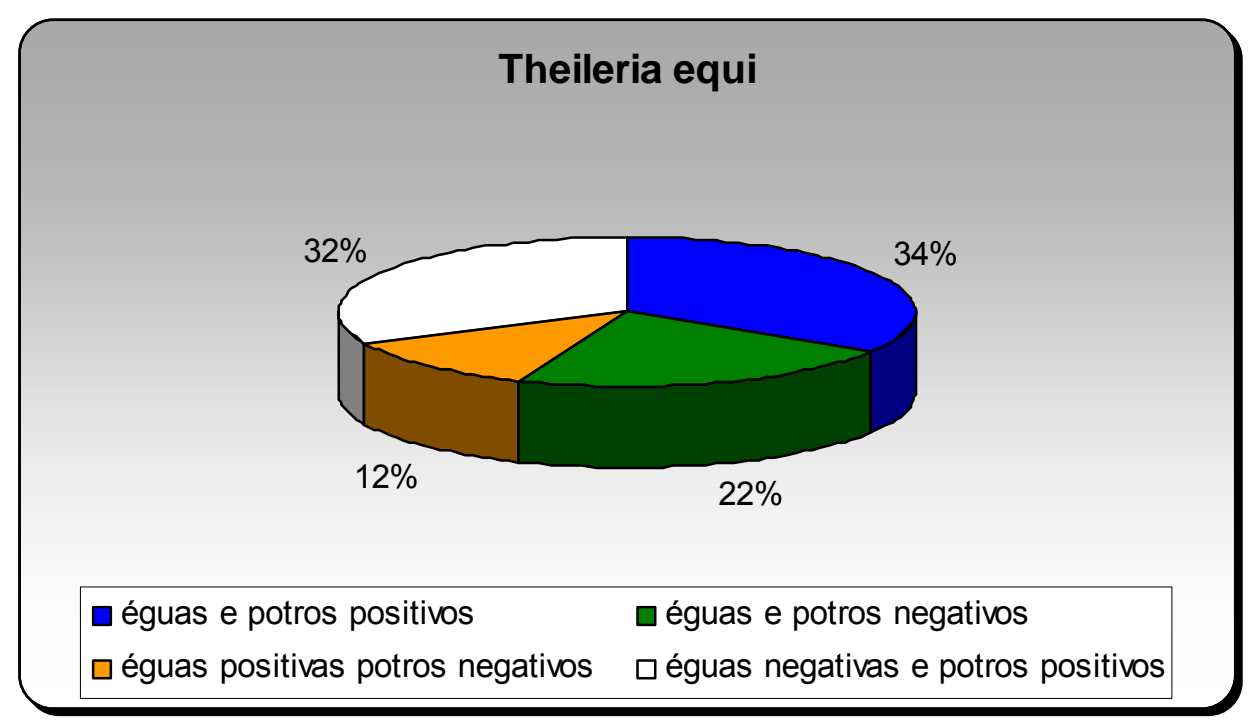

Gráfico 2 - Representação da porcentagem de éguas negativas ou positivas para Theileria equi em relação aos neonatos positivos ou negativos, no teste de RTPCR - São Paulo - 2006

Os resultados do teste de RT-PCR para Babesia caballi demonstraram que 8 (16\%) éguas foram positivas e 42 (84\%) negativas e que 1 (2\%) potro mostrou resultado positivo sendo este produto de uma égua também positiva, como demonstrado nos gráficos 3 e 4 . 


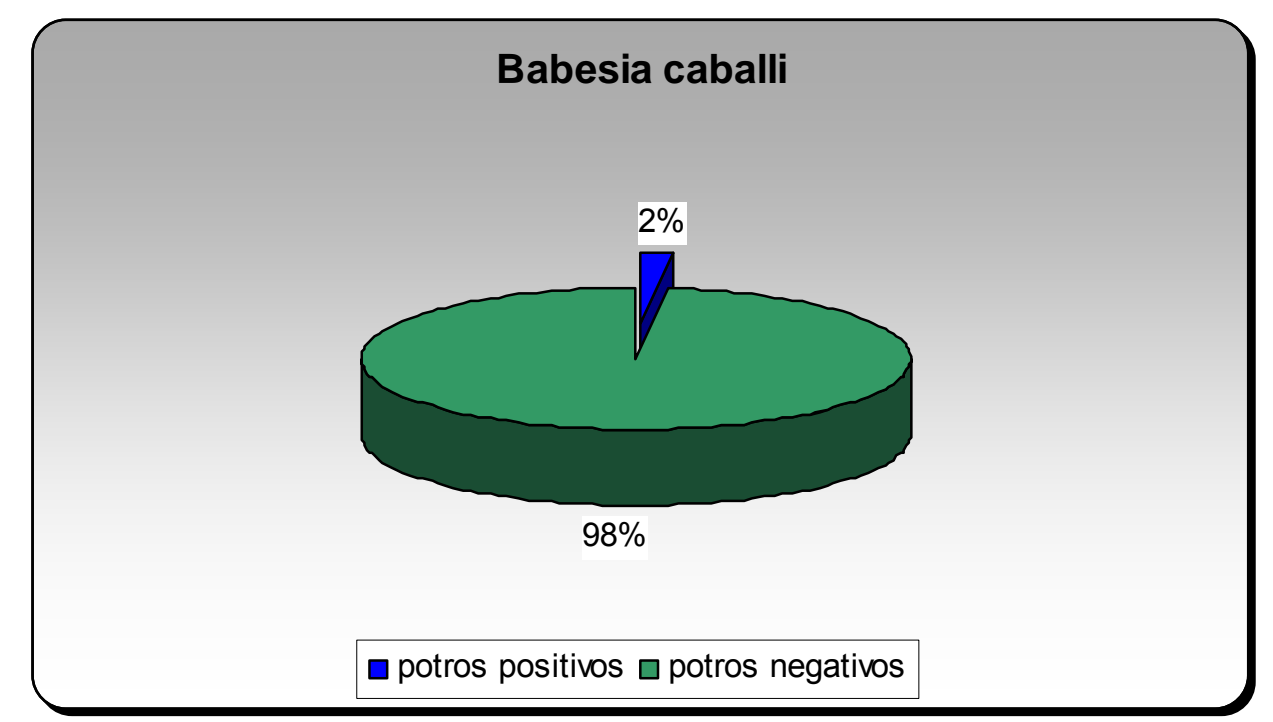

Gráfico 3 - Representação da porcentagem de potros nascidos positivos para Babesia caballi no teste de RT-PCR - São Paulo - 2006

\section{Babesia caballi}

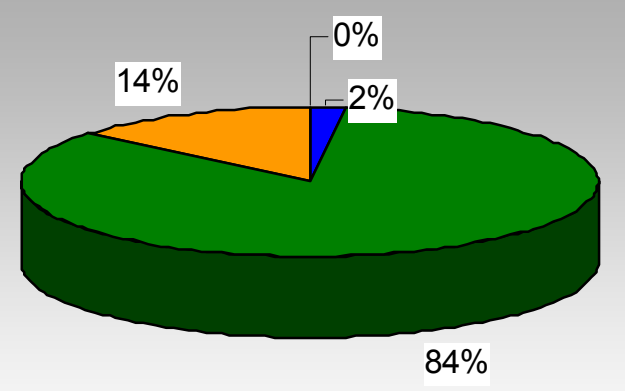

口 éguas e potros positivos

$\square$ éguas e potros negativos

$\square$ éguas positivas potros negativos $\square$ éguas negativas potros positivos

Gráfico 4 - Representação da porcentagem de éguas negativas ou positivas para Babesia caballi em relação aos neonatos positivos ou negativos, no teste de RTPCR - São Paulo - 2006 
As éguas que apresentaram resultado negativo para Theileria equi e cujos produtos apresentaram resultado positivo no exame de RT-PCR foram selecionadas para o teste sorológico de cELISA para Theileria equi.

Das 16 éguas selecionadas, aproximadamente 93,8\% (15 éguas em 16) resultaram em teste de cELISA positivo para a avaliação de anticorpos contra Theileria equi, como demonstrado na tabela 3.

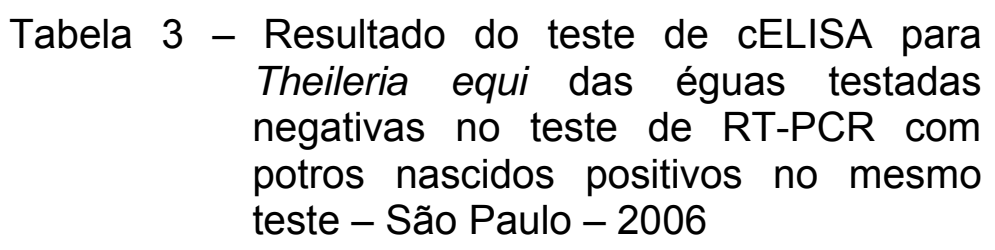

\begin{tabular}{lll}
\hline & \multicolumn{2}{c}{ Theileria equi } \\
\hline Amostra & RT-PCR & cELISA \\
\hline 1 & negativo & positivo \\
\hline 8 & negativo & positivo \\
\hline 9 & negativo & negativo \\
\hline 10 & negativo & positivo \\
\hline 13 & negativo & positivo \\
\hline 18 & negativo & positivo \\
\hline 20 & negativo & positivo \\
\hline 21 & negativo & positivo \\
\hline 24 & negativo & positivo \\
\hline 25 & negativo & positivo \\
\hline 30 & negativo & positivo \\
\hline 31 & negativo & positivo \\
\hline 32 & negativo & positivo \\
\hline 33 & negativo & positivo \\
\hline 36 & negativo & positivo \\
\hline 40 & negativo & positivo \\
\hline
\end{tabular}

Na somatória de animais positivos para Theileria equi em se considerando as duas provas (RT-PCR e cELISA) nota-se um total de 38 éguas, as quais geraram 33 neonatos também positivos no teste de RT-PCR para Theileria equi. Portanto $87 \%$ (33 
potros em 38) dos neonatos nascidos de éguas positivas para Theileira equi também nasceram positivos como demonstrado no gráfico 5 .

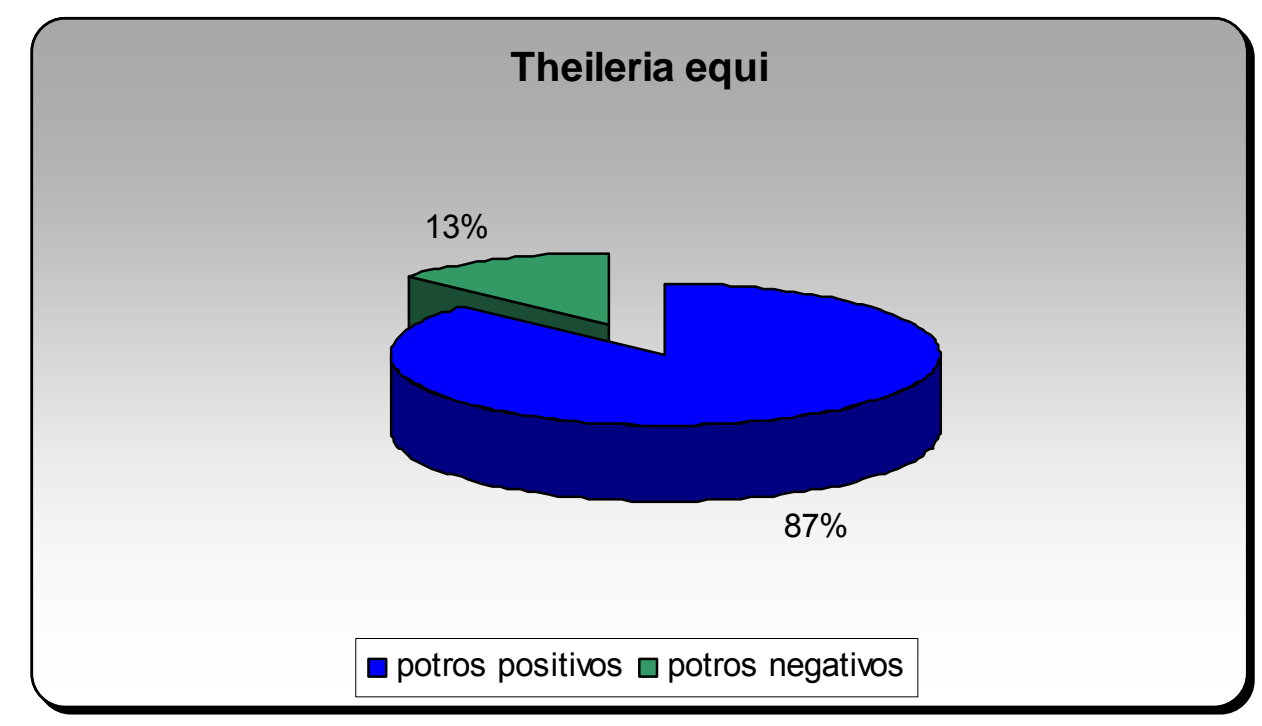

Gráfico 5 - Representação da porcentagem de potros positivos para Theileria equi, nascidos de éguas também positivas no teste de RT-PCR ou cELISA - São Paulo - 2006

Considerando-se apenas os potros positivos no teste de RT-PCR nascidos de éguas também positivas neste mesmo teste pode-se relatar que 73,9\% dos potros (17 potros em 23 ) nasceram positivos, como demonstrado no gráfico 6 . 


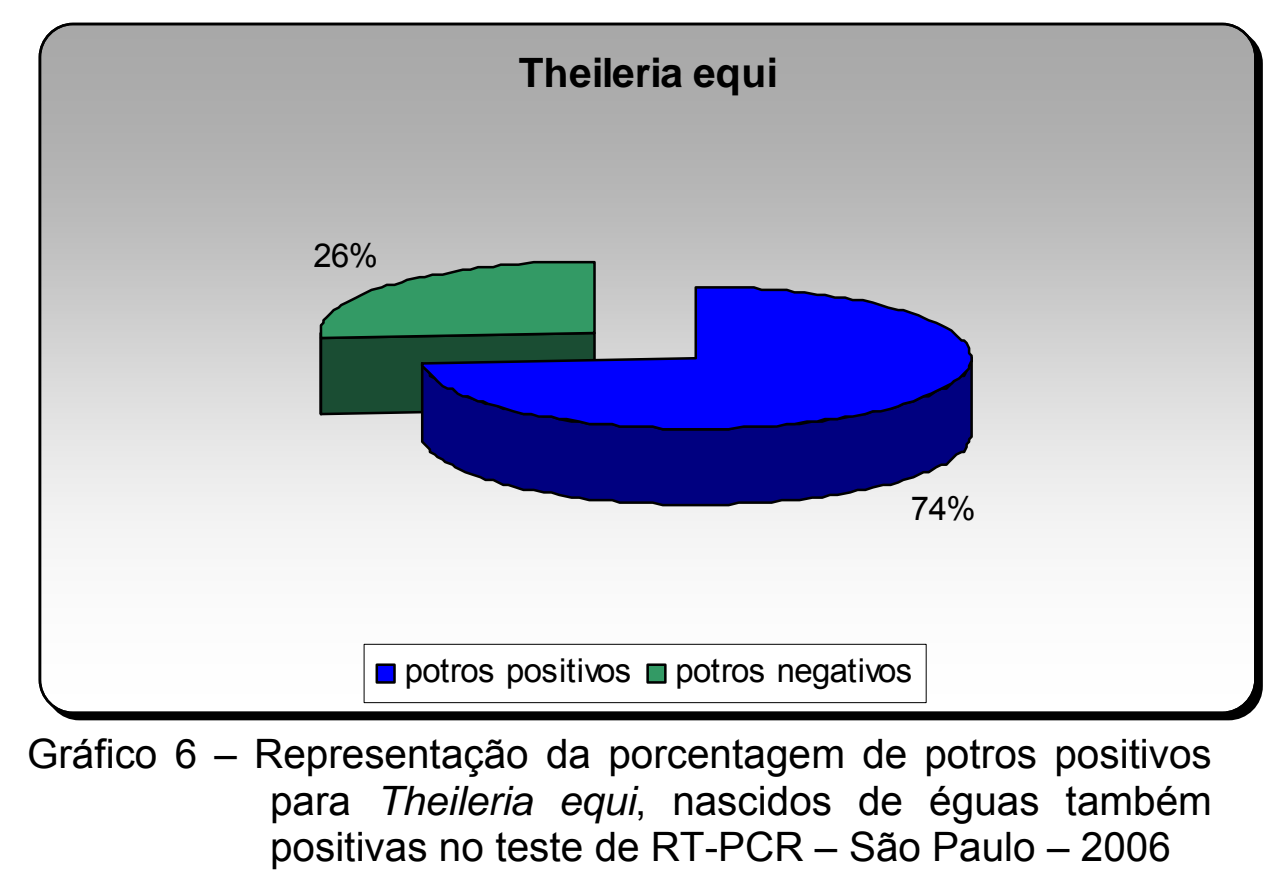

Embora exista um considerável número de potros positivos para Theileria equi nascidos de mães positivas ou mesmo negativas no teste de RT-PCR, não existe associação entre os resultados encontrados $(p=0,276)$, quando estes foram submetidos ao teste de Qui-quadrado. 


\section{DISCUSSÃO}

Assim como salientado por Phipps e Otter (2004), a Babesiose eqüina é uma importante afecção parasitária sanguínea que pode acometer os cavalos de maneira crônica sem quaisquer manifestações clínicas. Portanto pode-se dizer que existem muitos animais na equideocultura nacional que são portadores da infecção, mas que não apresentam sintomas clínicos, a não ser que um fator prévio de estresse favoreça a parasitemia e o aparecimento de sintomas comuns como hiporexia, febre e edema nos membros. Um dos fatores que comprova estas descrições literárias é o fato do elevado número de animais que apresentaram resultado positivo no teste de RT-PCR neste trabalho, tanto para Babesia caballi como para Theileria equi, e que sequer demonstravam alterações clínicas ao exame realizado durante a colheita sanguínea.

Como já descrito desde 1988 por Friedhoff e muitos outros autores após esta data, a criação de cavalos sofre consideráveis perdas frente à infecção dos animais por este importante e talvez único parasita intra-eritrocitário. Normalmente quem trabalha com animais alojados em grandes centros hípicos, como o Jockey Clube de São Paulo ou mesmo a Hípica Santo Amaro, se depara com animais com sintomatologia clínica compatível com Babesiose. Este fato prejudica em muito o treinamento e condicionamento de importantes e valiosos animais para competição, além de aumentar o custo de manutenção destes em condições favoráveis ao desempenho atlético.

Considerada e descrita por Reed e Bayly (2000) como uma doença endêmica em muitas áreas tropicais do mundo, pode-se dizer que no Brasil a Babesiose está 
amplamente distribuída por todo o território nacional, e mesmo em centros urbanos como São Paulo demonstra-se de forma cíclica e periódica, quer seja pela somatória de fatores predisponentes à afecção ou mesmo pela proliferação dos vetores naturais (carrapatos) em épocas como primavera e verão.

Phipps e Otter (2004) descreveram que após a infecção inicial os animais podem permanecer assintomáticos e carrearem um número pequeno de parasitas no organismo por poucos anos nos casos de Babesia caballi e provavelmente durante toda a vida no caso de Theileria equi. Pode-se concordar, já que animais sorologicamente positivos e que são preparados e tratados para exportação para países livres da doença como os Estados Unidos resultam em cronicidade na manutenção sérica de anticorpos para Theileria equi ao exame de cELISA e rapidamente se convertem em soronegativos para Babesia caballi.

Muitas destas situações, como a diferença na resposta às terapias descritas por Corrêa et al. (2004) podem ser explicadas pelo diferente ciclo intra-linfocitário prévio da Theileria equi diferente da Babesia caballi.

Estudos epidemiológicos no Brasil tentam elucidar quais os verdadeiros carrapatos envolvidos no ciclo de transmissão das diferentes Babesias. Guimarães et al. (1998) admite que o Boophilus tenha importância relevante na transmissão da Theileria equi, portanto vem sendo considerado o principal vetor de transmissão, mas mesmo em fazendas ou haras isolados da criação de bovinos e altamente controlados quanto à infestação do Boophilus nos cavalos demonstram incidência relativamente alta na presença de Theileria equi nos eqüinos de diferentes idades. Esta inadequação no entendimento da transmissibilidade pela ausência do principal carrapato vetor da Theileria equi é que impulsionou a idéia de realização deste trabalho, considerando-se 
a possibilidade de transmissão congênita e manutenção do parasita em situações de ausência de ixididiose.

Não concordamos com pesquisadores como Knowles e Uniss-Floid (1983) que admitem a possibilidade de transmissão da Babesiose por dípteros hematófagos, já que assim como descrito por Phipps e Otter (2004) não existe comprovação desta forma de transmissão, além disso, sabe-se que a probócide presente no aparelho bucal da maioria dos insetos não seria capaz de sugar hemáceas contaminadas com Babesia caballi ou mesmo Theileria equi e mantê-las até que um animal sadio fosse picado e contaminado por estes insetos. Portanto meios de transmissão como o transplacentário, pelo menos para a Theileria equi devem ser muito mais importantes na manutenção do ciclo parasitário destes protozoários do que transmissões por insetos hematófagos ou mesmo por fômites contaminados de maneira iatrogênica, como agulhas ou seringas.

Sabidamente a classe veterinária admite a alta incidência de resultados falso negativos quando do exame feito por esfregaços sanguíneos de cavalos suspeitos ou mesmo com sintomas evidentes de Babesiose, portanto seria muita coincidência acidentalmente uma pessoa utilizar a mesma seringa ou agulha em diferentes animais e conseguir carrear os protozoários sanguíneos afim de contaminar animais sadios, o que não se faz admitir que utensílios médicos não devam ser descartáveis e jamais utilizados para mais de um animal.

Assim com descrito por Phipps e Otter (2004) concorda-se que Portugal seja uma região altamente endêmica para a Babesiose, haja visto que muitas éguas utilizadas neste trabalho também foram importadas deste país, e no trabalho realizado por estes autores admiti-se que animais soropositivos foram importados à Inglaterra. 
Não diferente, na década de 70 a 80, muitas éguas e outros animais da raça de Puro Sangue Lusitano, possivelmente positivos, foram trazidas para o Brasil numa forma de importação inadequada pela ausência de barreiras sanitárias, como exame negativo para piroplasmose quando da entrada de animais ao território nacional, mesmo por que somos admitidamente país portador desta afecção. Portanto concordase com a descrição realizada pelos autores de que animais criados na Inglaterra, mas nascidos em Portugal poderiam ser portadores da Babesiose. O que não se pode concordar é com a simples conclusão de que possivelmente a transmissão seja transplacentária, já que dois animais nascidos na Inglaterra testaram sorologicamente positivos quando na fase adulta, logicamente admitindo-se que no Reino Unido não há carrapatos vetores de transmissão para esta afecção. Como o exame realizado foi o de esfregaço sanguíneo além do Teste de Fixação de Complemento, o simples fato de positividade no soro não justifica a presença da doença, a não ser tendo-se o exame microscópico de esfregaço em lâmina também positivo o que ocorreu em apenas um dos animais.

Muito se questiona na verdadeira fidedignidade do resultado positivo de testes sorológicos como o Teste de Fixação de Complemento ou mesmo de cELISA, os quais pesquisam a presença de imunoglobulinas circulantes, no primeiro caso mais especificamente $\lg M$ e no segundo $\lg G$, na detecção de animais doentes. Sabe-se que mesmo na ausência do protozoário muitas destes anticorpos circulantes permanecem por meses ou anos no organismo animal, mimetizando uma vacinação contra a piroplasmose.

Logicamente testes que detectem a presença do parasita como é o caso do esfregaço sanguíneo são melhores na afirmação do estado de doença de animais 
positivos, fato que poderia ser considerado no exame de PCR, mas que pelo menos até a atualidade não é verdade pela presença de falsos negativos. Testes como o PCR e o esfregaço sanguíneo são fundamentais ao diagnóstico desde que o resultado seja positivo, mas para resultados negativos não se pode afirmar com total segurança a ausência do protozoário no organismo.

Diferente do relatado por Phipps e Otter (2004) na Inglaterra como descrição de dois casos de transmissão transplacentária da Theileria equi, optou-se pela realização e colheita de potros logo nas primeiras horas de vida e posterior realização do teste de RT-PCR inibindo-se qualquer possibilidade da existência de outra forma de contaminação dos neonatos, como por exemplo, contato com carrapatos com tempo para multiplicação e desenvolvimento de parasitemia. Além disso, optou-se pelo teste de RT-PCR pela praticidade na determinação de animais positivos para esta afecção. A opção de não realização de testes amplamente divulgados e considerados adequados no controle de animais positivos para Babesia como o teste de cELISA se deu pela inadequação da mensuração de imunoglobulinas nos potros jovens, já que se estes mamassem o colostro poderiam adquirir os anticorpos passivos maternais transferidos após a mamada (MCGUIRE et al., 1977).

Diferente da simples observação clínica de Babesiose em neonatos ou potros jovens que pudessem sugerir a existência de transmissão congênita desta afecção, como descritos em trabalhos de Donatien et al. (1924) e Guimarães et al. (1954), este trabalho atingiu seu objetivo em comparar a existência do parasita em colheitas sanguíneas da mãe e do potro recém nascido, mesmo antes de qualquer possibilidade de contato com possíveis vetores da infecção, fato inédito na literatura. Como o trabalho foi desenvolvido em regiões consideradas endêmicas para a Theileria equi e 
Babesia caballi, a colheita precoce nos animais recém nascidos isenta o risco de infestação por outra via de contaminação, permitindo a comparação entre a transmissão in útero da Theileria equi ou da Babesia caballi, esta última admitida como improvável de transmissão congênita pelo seu tamanho, o que inibi o contato em possíveis micro-lesões na espessa placenta epiteliocorial das éguas.

Como descrito por Reed e Bayly (2000) a Theileria equi esta no grupo das pequenas babésias que medem cerca de 1 a $2 \mu \mathrm{m}$ diferente das grandes Babesias como a Babesia caballi que pode medir de 3 a $5 \mu \mathrm{m}$ de comprimento dificultando sua transposição pela placenta das éguas. Portanto considera-se que achados como o potro deste trabalho que resultou em positivo para Babesia caballi logo ao nascimento pode ser secundário a contaminação sanguínea materna-fetal no período do parto.

Dificilmente a Theileria equi, assim como a Babesia caballi são observadas ao microscópio óptico após realização de esfregaço sanguíneo quando a parasitemia é baixa, além disso, a Theileria equi pode facilmente ser confundida com artefatos de técnica pelo seu tamanho reduzido (KERBER, 2004). Características como estas limitam ainda mais o exame por esfregaço sanguíneo em potros jovens, principalmente pela observação de casos onde os animais nascem sadios e demoram dias ou meses para desenvolverem sintomatologia clínica mesmo após contaminação congênita mimetizando os animais assintomáticos descritos por Phipps e Otter (2004). Com base nas limitações de testes como o esfregaço sanguíneo pode-se observar que um exame como o PCR pode proporcionar uma avançada arma na pesquisa de animais portadores destes protozoários.

Em diversos trabalhos descreve-se que um dos vetores naturais de maior importância no ciclo de transmissão da Theileria equi seria o Boophilus microplus, haja 
visto que a presença de ixodidiose deste ectoparasita aumenta a prevalência de casos de Babesiose por Theileria equi (CORRÊA et al., 2004; KERBER, 2004). Deve-se salientar que o Boophilus microplus é um carrapato monoxeno, ou seja, realiza seu ciclo em apenas um hospedeiro, fato que limita a possibilidade de transmissão da doença, já que não realiza repasto em mais de um animal. Além disso, não existe transmissão transovariana entre gerações neste carrapato, o que restringe a transmissão numa casuística acidental e que pelas observações clínicas em diversos haras no Brasil não pode ser considerada como relevante, e sim contraditório à grande incidência de casos de Theileria equi em diversas regiões do país. Portanto através da caracterização de transmissão transplacentária pode-se dizer que epidemiologicamente esta via de contaminação talvez tenha uma grande importância no aparecimento de animais doentes ou mesmo portadores assintomáticos.

Nota-se que o controle ectoparasitário com muitos produtos carrapaticidas, como exemplo do grupo dos piretróides, somado a fatores como rodízio de pastagens e isolamento da criação de eqüinos e bovinos limita consideravelmente a infestação dos cavalos pelo Boophilus microplus. Mesmo assim o levantamento parasitário através de técnicas como esfregaço sanguíneo ou mesmo o teste de Fixação de complemento caracteriza a ocorrência esporádica de casos de Theileria equi, que possivelmente esteja utilizando de outra forma de transmissão que não os vetores biológicos naturais.

A correlação encontrada em estudos epidemiológicos realizados por Kerber et al. (1999) demonstraram que a presença de outro importante carrapato que parasita os eqüinos denominado Amblyoma cajennense aumenta a possibilidade do aparecimento de animais acometidos pela Theileria equi, apesar de nenhum estudo ter comprovado biologicamente ser este ácaro responsável pela transmissão da Babesiose. É fato que 
um parasita como o Amblyoma tem maior chance de transmitir a Theileria equi já que trata-se de um carrapato trioxeno, ou seja, necessita de três hospedeiros para completar seu ciclo de vida. Diferente do que foi discutido em relação ao Boophilus, este carrapato tem seu controle dificultado pela presença de diversos hospedeiros silvestres que dividem a parasitemia com os eqüinos, como é o caso das diferentes espécies de capivara. Mas o mesmo controle carrapaticida descrito anteriormente também é bastante eficaz nesta espécie de carrapatos, portanto nota-se que haras isentos de ixodidiose, quer seja pelo B. microplus como pelo $A$. Cajennense ainda apresenta incidências esporádicas de Babesiose, fato que sedimenta ainda mais a suspeita de transmissão transplacentária descrita e comprovada neste trabalho.

O acompanhamento das éguas e potros deste experimento pode revelar que muitos animais mesmo sendo parasitados, como é o caso das 31 éguas positivas encontradas no teste de RT-PCR e dos 34 potros positivos no mesmo teste, podem não apresentar qualquer sintomatologia compatível com a Babesiose, fato comparável ao descrito por Reed e Bayly (1998) que relataram que eqüinos criados em regiões endêmicas costumam ser portadores de Babesia, muitas vezes sem sintomas.

Diferente do que tem sido descrito por muitos autores como Knowles (1980) e Zaugg (1990) animais portadores de Babesia sp. normalmente não demonstram sintomas como: ataxia, secreção nasal, hemoglobinúria, que são sintomas observados com maior freqüência em animais criados em regiões isentas da afecção e que agudamente sejam contaminados pela mesma. No nosso país, corretamente considerado endêmico tanto para Babesia caballi como para Theileria equi, é comum observar-se sintomas clássicos como febre, hiporexia ou anorexia e edema de membros, em conseqüência à anemia causada pela hemólise intravascular. Esta 
hemólise pode sem dúvida resultar no aparecimento de petéquias ou mesmo icterícia das membranas mucosas, ocular, gengival e genital, assim como descrito por Allsopp (1994).

Assim como descrito na literatura nos casos de Theileria equi a parasitemia normalmente é maior e a apresentação clínica mais aguda, inclusive podendo levar muitos eqüinos à óbito se não tratados adequadamente (KERBER et al., 1999).

Almeida (2001) descreveu que os animais infectados por Theileria equi persistem infectados por anos ou até por toda a vida diferente do que ocorre com a Babesia caballi, que causa infecções menos persistentes e menos estáveis no organismo. O fato de encontrar-se no teste de RT-PCR um número muito maior de éguas acometidas por Theileria equi (23 em 50 éguas) pode ser comprobatório desta relação epidemiológica da diferença no número de casos de Babesia caballi (8 em 50 éguas).

Euzeby et al. (1980) descreveram que a maioria dos eqüinos infectados reage fortemente à presença do estímulo antigênico da Babesiose produzindo anticorpos tipo $\lg G$, fato que pode ser observado no grande número de éguas positivas na pesquisa pelo teste de cELISA para Theileria equi (15 éguas em 16).

O ponto central desta pesquisa era a demonstração da possibilidade de transmissão transplacentária da Theileria equi, portanto foram encontrados 16 potros positivos com suas mães negativas no teste de RT-PCR. Mas assim como descrito por Kerber (2004) o teste de PCR pode apresentar falsos negativos, principalmente em animais cronicamente infectados, possivelmente pelo baixo número de parasitas circulantes e portanto disponíveis na amostra colhida. 
Considera-se o PCR um teste altamente sensível e extremamente eficiente para o diagnóstico de Theileria equi e da Babesia caballi, mas como já relatado por Bahirruddin et al. (1999) a possibilidade de resultados falso negativos pode gerar a necessidade de outros exames complementares ao diagnóstico, como é o caso do teste de cELISA ou mesmo Fixação de Complemento. Portanto a opção de reavaliação das éguas testadas negativas no RT-PCR, mas que tiveram seus potros logo ao primeiro dia de vida positivos no mesmo teste é baseada na possibilidade de falsos negativos. Neste trabalho optou-se pela realização do teste de cELISA nas 16 mães negativas com potros positivos, fato que pode elucidar que pelo menos 15 delas tinham níveis de anticorpos detectáveis para Theileria equi, podendo estar relacionado a infecções crônicas.

Embora não exista uma relação estatística entre os potros testados como positivos para Theileria equi e as éguas também positivas no teste de RT-PCR pode-se dizer que a possibilidade de transmissão transplacentária existe, principalmente porque $87 \%$ dos potros nascidos de éguas positivas no teste de PCR ou cELISA nasceram positivos, demonstrando uma elevada possibilidade de contaminação na vida in útero. Diferentemente o número de potros que foram positivos para Babesia caballi (1 em 50 potros) não permite a correlação estatística ou mesmo suposições de transmissão transplacentária, fato esperado pela incapacidade deste parasita de atravessar a placentação epiteliocoreal das éguas. Como anteriormente descrito este neonato positivo pode estar relacionado a um possível contato materno-fetal sanguíneo nos pródromos do parto, mesmo por que a possibilidade de teste falso positivo no exame de RT-PCR é muito pequena. 
Como os resultados obtidos no teste diagnóstico de RT-PCR são qualitativos, ou seja, distribuídos entre positivos ou negativos, não existe a possibilidade de cálculo estatístico de correlação entre os resultados de mães e filhos, mas o fato de encontrarse potros positivos nascidos de éguas positivas nos comprova a ocorrência de transmissão transplacentária. 


\section{CONCLUSÕES}

Ao fim deste experimento as seguintes conclusões podem ser destacadas:

O exame de RT-PCR empregado para diagnóstico da Babesiose foi adequado na detecção de infecção em animais neonatos.

Embora o teste de RT-PCR para Babesia seja altamente sensível e específico pode resultar em falsos negativos, nas amostras sanguíneas.

O teste de cELISA comprova a existência de animais positivos para Theileria equi assintomáticos.

Existe a possibilidade de transmissão transplacentária da Theileria equi.

A possibilidade de transmissão transplacentária da Babesia caballi não pode ser comprovada. 


\section{REFERÊNCIAS}

ALLSOPP, M. T.; CAVALIER-SMITH, T.; DE WALL, D. T.; ALLSOPP, B. A. Phylogeny and evolution of the piroplasms. Parasitology, n.108,p. 147-152, 1994. Pt. 2.

ANO, H.; MAKIMURA, S.; HARASAWA, R. Detection of babesia species from infected dog blood polymerase chain reaction. The Journal of Veterinary Medical Science, $v$. 62, n. 1, p. 111-113, 2001.

BASHIRUDDIN, J. B.; CAMMA, C.; REBELO, E. Molecular detection of Babesia equi and Babesia caballi in horse blood by PCR amplification of part of the 16S rRNA gene. Veterinary Parasitology, v. 1-2, n. 84, p. 75-83, 1999.

BARRY, D. N.; RODWELL, B. J.; TIMMS, P.; MCGREGOR, W. A Microplate enzyme immunoassay for detecting and measuring antibodies to Babesia bovis in cattle serum. Australian Veterinary Journal, v.59, n.5, p.136-140, 1982.

BATTSETSEG, B.; XUAN, X.; IKADAI, H.; BAUTISTA, J. L.; BYAMBAA, B.; BOLDBAATAR, D.; BATTUR, B.; BATTSETSEG, G.; BATSUKH, Z.; IGARASHI, I.; NAGASAWA, H.; MIKAMI, T.; FUJISAKI, K. Detection of Babesia caballi and Babesia equi in the Dermacentor nutalli adult tock. International Journal for Parasitology, v. 31, n. 4, p. 384-386, 2001.

BIER, M.; FATH, S.; TSCHOCHNER, H. The composition of the RNA polymerase I transcription machinery switches from initiation to elongation mode. FEBS Letters. $v$. 564, n. 1-2, p. 41-46, 1989.

BOSE, R.; JORGENSEN, W. K.; DALGLIESH, R. J.; FRIEDHOFF, K. T.; DE VOS, A. J. Current state and future trends in the diagnosis of babesiosis. Veterinary Parasitology, v. 57, n. 1-3, p. 61-74, 1995.

BOSE, R.; PEYMANN, B. Diagnosis of Babesia caballi infections in horses by enzymelinked immunosorbent assay (ELISA) and western blot. International Journal for Parasitology, v. 24, n. 3, p. 341-346, 1994.

BRUNING, A. Equine Piroplasmosis: an update on diagnosis, treatment and prevention. The British Veterinary Journal, v. 152, n. 2, p. 139-151, 1996. 
COLLADO, J. G.; FLECHTMANN, C. H. W. Ácaros de importância médico veterinária. 3. ed. São Paulo: Nobel, 1985, p. 68-75.

COLLADO, J. G.; FLECHTMANN, C. H. W. Ácaros de importância médico veterinária. 3. ed. São Paulo: Nobel,1985, p. 78-82.

CORREAA, R. R.; RONCATI, N. V.; BONAGURA, G. Estudo da eficácia terapêutica do Dipropionato de Imidocarb no tratamento da Piroplasmose Eqüina. A Hora Veterinária, v. 24, n. 144, p. 53-58, 2005.

CREPALDI, C. A. Babesiose eqüina. 2004. 68p. Trabalho de Conclusão de Curso Faculdade de Medicina Veterinária, Universidade Anhembi Morumbi, São Paulo, 2004.

DE WALL, D. T.; VAN HEERDEN, J.; POTGIETER, F. T. As investigation into the clinical pathological changes and sorological response in horses experimentally infected with Babesia equi and Babesia caballi. The Onderstepoort Journal of Veterinary Research, v. 54, n. 4, p. 561-568, 1987.

DONATIEN, A. L.; LESTOQUARD, F.; SAUSEAU, E.; MAUBARET, P. Transmission de Piroplasma caballi de la mère au foetus. Bulletin Societe Pathologie Exotique, v. 27, p. 433-435, 1924.

EUZEBY, J.; MOREAU, Y.; DUBOR, M.; GAUTHEY, M. Immunily in babesiosis experimental chemo-immunization. Bulletin Societé Sciences Veterinaires Medicine Comparêe-Lyon, v. 82, p. 137-142, 1980.

FERREIRA, A. W. Diagnóstico laboratorial. 1. ed. Rio de Janeiro: Guanabara Koogan, 1996, 302 p.

FORTES, E. Parasitologia Veterinária. 1. ed. Rio Grande do Sul: Sulina, 1987, p.102111.

FORTES, E. Parasitologia veterinária. 1. ed. Rio Grande do Sul: Sulina, 1987, p. 6871. 
FRIEDHOFF, K. T. Transmition of Babesia. In: Babesiosis in domestic animals and man. Boca Raton, Florida: CRC Press, 1988, p. 23-52.

FRIEDHOFF, K. T. Die piroplasmen der equiden. Bedeutung für den internationalen Pferdeverkehr. Berliner um Münchener Tierärztliche Wochensschrift, v. 95, n. 19, p. 368-374, 1982.

GERSTENBERG, C.; ALLEN, W. R.; PHIPPS, L. P. Mechanical transmission of Babesia equi infection in a British herd of horses. In: INTERNACIONAL CONFERENCE ON EQUINE INFECTIOUS DISEASE, 8. 1998, Proceedings..., Dubai, Newmarket. R \& W Publications, 1998. p. 217-222.

GUIMARÃES, L. M.; ARAUJO, T. L.; SALLES GOMES, C. E. Nutaliose congênita em eqüinos puro sangue de corridas no estado de São Paulo. Revista da Faculdade de Medicina Veterinária de São Paulo, v. 5, n. 2, p. 183-186,1954.

GUIMARÃES, A. M.; LIMA, J. D.; RIBEIRO, M. F. B. Sporogony and experimental transmission of Babesia equi by Boophilus microplus. Parasitology Research, v. 84, n. 4, p. 323-327, 1998.

GUIMARÃES, A. M.; LIMA, J. D.; TAFURI, W. L.; RIBEIRO, M. F. D.; SCIAVICCO, C. J. S.; BOTELHO, A. C. C. Clinical and histopathological aspects of splenectomized foal infected by Babesia equi. Journal of Equine Veterinary Science, v. 17, n. 4, p. 211216, 1997.

GÖTZ, F. Untersuchungen über die Brauchbarkeit von ELISA, IFAT, IHA, und KBR zum Nachweis von Babesia equi Infetionen.1982. 212p. Dissertation MS, Veterinary Faculty, University of Munich, Munich, 1982.

HEUCHERT, C. M.; DE, GIULLI, J. R. V.; DE ATHAIDE, D. F.; BOSE, R.; FRIEDHOFF, K. T. Seroepidemiologic studies on Babesia equi and Babesia caballi infections in Brazil. Veterinary Parasitology, v. 85, n. 1, p. 1-11, 1999.

HIRATO, K.; NONOMIYA, N.; UWANO, Y.; KUTII, T. Studies on the complement fixation reaction for equine piroplasmosis. Japanese's Journal of Veterinary Sciences, v. 7, p. 204-205, 1945. 
HOURRIGAN, J. L.; KNOWLES, R. C. Equine piroplasmosis. American Asociation Equine Practice Newsletter, v. 1, p. 119-128, 1979.

JAIN, N. C. Essentials of veterinary hematology. Philadelphia, Lea \& Febiger, 1993, $183 \mathrm{p}$.

JANEWAY, C. A.; TRAVERS, P.; WALPORT, M.; CAPRA, J. D. Indução e avaliação da resposta immune. In: JANEWAY, C. A.; TRAVERS, P.; WALPORT, M.; CAPRA, J. D. Imunobiologia. São Paulo: Elsevier, 1999, p. 61-62

JANEWAY, A. C.; TRAVERS, P.; WALPORT, M.; SHLOMCHICK, M. Imunobiologia. São Paulo, Varela, 2001, p. 646-647.

KERBER, C. E.; FERREIRA, F.; PEREIRA, M. C. Control of equine piroplasmosis in Brazil. Onderstepoort Journal of Veterinary Research, v. 66, n. 2, p. 123-127, 1999.

KNOWLES, R. C. Equine piroplasmosis. Equine Practice. v. 2, n. 1, p. 10-12, 1980.

KNOWLES, R. C.; UNISS-FLOYD, R. Equine Piroplasmosis (Babesiosis) of the Babesia caballi type. Equine Pratice, v. 5, n. 3, p. 18-22, 1983.

KRATZER, I. Die Brauchbarkeit der Babesia rodhaini Antigene zum Nachweis von babesia Infectionen im ELISA.1979. 80 p. Dissertation. Veterinary Faculty, University of Munich, 1979.

KUTTLER, K. L.; GOFF, W. L.; GIPSON, C. A.; BLACKBURN, B. O. Serologic response of Babesia equi - infected horses as measured by complement-fixation and indirect fluorescent antibody tests. Veterinary Parasitology, v. 26, n. 3-4, p. 199-205, 1988.

LAVERAM, A. Contribuition a l'etude de Piroplasma equi. Comptes Rendus des Seances de la Societé de Biologie, v. 53, p. 385-388, 1901.

LEITE, R. C.; OLIVEIRA, P. R.; LOPES, C. M. L.; FREITAS, C. M. V. Alguns aspectos epidemiológicos das infestações por Amblyomma cajennense: uma proposta de controle e estratégia. Departamento de Medicina Veterinária e Preventiva-Escola Veterinária UFMG, 1988, p. 9-14. (Apostila) 
LEVINE, N. D. Apicomplexa: The Piroplasm. In: lowa: lowa State University Press, 1985, 414 p. Veterinary protozoology,

MAHONEY, D. G. Babesia of domestic animals. In: KREIER, J. P. Parasitic protozoa. New York: Academic Press. 1977. v. 4, p.1-52.

MARTIN, R. Equine piroplasmosis: the temporary importation of soropositive horses into Australia. Australian Veterinary Journal, v. 77 n. 5, p. 308-309, 1999.

MASUDA, A.; VAZ, I. S.; FERREIRA, C. A. S.; FARIAS, S.; LEAL, A. T.; FREITAS, D. R. J. Ciclo Biológico do Carrapato. Departamento de Biologia Molecular e Biotecnologia e Centro Biotécnico do Estado do Rio Grande do Sul UFRGS. Disponível em: <www.ufrgs.br/depbiot/2001/carrapat.htm>. Acesso em : 08 de outubro de 2005.

MCGUIRE, T. C.; CRAWFORD, T. B.; HALLOWELL, A. L. Failure of colostral immunoglobulin transfer as na explanation for nost infections and deaths in neonatal foals. Journal of the American Veterinary Medical Association, v. 170, n. 1, p. 13021304, 1977.

MEHLHORN, H.; SCHEIN, E. Redescription of Babesia equi Laveran, 1901 as Theileria equi Mehlhorn, Schein. Parasitology Research, v. 84, n. 6, p. 467-475, 1998.

MERKLE, F. J. Untersuchungen über die Brauchbarkeit von KBR, IFAT und ELISA zum Nachweisder Babesia caballi-infektion des Pferdes, 1983, Dissertation MS, Veterinary Faculty, University of Munich, Munich, 1983.

NICOLAIEWSKY, T. B.; RICHTER, M. F.; LUNGE, V. R.; CUNHA, C. W.; DELAGOSTIN, O.; IKUTA, N.; FONSECA, A. S.; SILVA, S. S.; OZAKI, L. S. Detection of Babesia equi (Laveran, 1901) by nested polymerase chain reaction. Veterinary Parasitology. v. 101, n. 1, p. 9-21, 2001.

NUTTALL, G. H. F.; STRICKLAND, C. On the occurrence of two species of parasites in equine piroplamoses or biliary fever. Parasitology, v. 5, n. 1, p. 65-83, 1912.

PHIPPS, L. P.; OTTER, A. Transplacental transmission of Theileria equi in two foals born and reared in the United Kingdom. Veterinary Record, v. 154, n. 17, p. 406-408, 2004. 
POSNETT, E. S.; FEHRSEN, J.; DE WALL, D. T.; AMBROSIO, R. E. Direction os Babesia equi in infected horse and carrier animals using a DNA probe. Veterinary Parasitology, v. 39, n. 1-2, p. 19-32, 1991.

PURNELL, R. E. Babesiosis in various hosts. In: RISTIC, M., AND KREIER, J. P. Babesiosis. New York: Academic Press, 1981, p. 25-63.

PURNELL, R. E.; HENDRY, D. J.; BIDWELL, D. E.; TURP, P. Microplate enzymelinked immunosorbent assay for antibody to Babesia divergens in cattle. The veterinary Record, v. 99, n. 6, p. 102, 1976.

RAMPERSAD, J.; CESAR, E.; CAMPBELL, M. D.; SAMLAL, M.; AMMONS, D. A field evaluation of PCR for the routine detection of Babesia equi in horses. Veterinary Parasitology, v. 114, n. 2, p. 81-87, 2003.

REED, S. M.; BAYLY, W. M. Medicina interna equina. Rio de Janeiro: Guanabara Koogan, 2000, $491 \mathrm{p}$.

SCHEIN, E. Equine babesiosis. In: RISTIC, M. Babesiosis of domestic animals and man. Boca Raton, Florida: CRC Press, 1988, p.197-208.

SCHEIN, E; REHBEIN, G, VOIGT, W. P, ZWEYGARTH, E. Babesia equi (Laveran 1901) 1.Development in horses and in lymphocyte culture. Tropenmed Parasitology, v. 32 , n. 4 , p. $223-227,1981$.

SCROFERNER, L. M.; POHLMANN, R. P. Imunologia basica aplicada, Rio Grande do Sul, Porto Alegre: Sagra Luzato, 1998, p. 24-26.

SIMPSON, C. F.; NEAL, F. C. Ultrastructure of Babesia equi in ponies treated with imidocarb. American Journal Veterinary Research, v. 41, n. 2, p. 267-271, 1980.

STEPANOVA, N. I.; PETROVSKII, V. V. Serological diagnosis of nuttalliosis in horses. Veterinariya (Moscow), v. 1, p. 56-58, 1975.

STILLER, D.; COAN, M. E. Recent developments in elucidating tick vector relationships for anaplasmosis and equine piroplasmosis. Veterinary Parasitology, v. 57, n. 1-2, p. 97-108, 1995. 
TAYLOR, W. M.; BRYANT, J. E.; ANDERSON, J. B.; WILKENS, K. H. Equine piroplasmose in the United States-a review. Journal of the American Veterinary Medical Association, v. 155, n. 6, p. 915-919, 1969.

TIZARD, R. I. Imunologia veterinária, São Paulo: Roca, 1998, p. 94-96.

TIZARD, R. I. Imunologia veterinária, São Paulo: Roca, 1998, p. 327-329.

URQUHART, G. M.; AEMOUR, J.; DUNCAN, J. L.; DUN, A. M.; JENNINGS, F. W. Parasitologia veterinária, Rio de Janeiro: Guanabara Koogan, 1998, p. 210-214.

VAZ, C., CALICH, V. Imunobiologia. São Paulo: Revinter, 2001, p. 50-51.

YOUNG, A.; PURNELL, R. E. Evalution of dried blood samples as a source of antibody in the micro ELISA test for Babesia divergens. The veterinary record, v. 106, n. 3, p. $60-1,1980$.

ZAUGG, J. L. Babesiosis. In: SMITH, B. P., 2.ed: Large animal internal medicine, St Louis, Mosby-Year Book, 1990, 1787 p.

WEILAND, G. Species-specific serodiagnosis of equi piroplasma infections by means of complement fixation test (CFT), immunofluorescence (IIF), and enzyme-linked immunosorbent assay (ELISA). Veterinary Parasitology, v. 20,n. 1-2, p. 43-48, 1986.

WEILAND, G.; KRATZER, I. Fluoreszenz und enzymserologische Untersuchungen zum nachweis der latenten Hundebabesiose. Berliner und Münchener Tierärztliche Wochenschrift, v. 92, n. 20, p. 398-400, 1979. 


\section{APÊNDICE A - Resultado de RT-PCR tanto para Babesia caballi como para Theileira equi nas éguas e potros ao primeiro dia de nascimento}

\begin{tabular}{|c|c|c|c|c|}
\hline \multirow[b]{2}{*}{ Amostra } & \multicolumn{2}{|c|}{ Theileria equi } & \multicolumn{2}{|c|}{ Babesia caballi } \\
\hline & égua & potro & égua & potro \\
\hline 1 & negativo & positivo & positivo & negativo \\
\hline 2 & negativo & negativo & positivo & negativo \\
\hline 3 & negativo & negativo & negativo & negativo \\
\hline 4 & negativo & negativo & negativo & negativo \\
\hline 5 & positivo & positivo & negativo & negativo \\
\hline 6 & positivo & positivo & negativo & negativo \\
\hline 7 & negativo & negativo & negativo & negativo \\
\hline 8 & negativo & positivo & negativo & negativo \\
\hline 9 & negativo & positivo & negativo & negativo \\
\hline 10 & negativo & positivo & negativo & negativo \\
\hline 11 & negativo & negativo & negativo & negativo \\
\hline 12 & positivo & negativo & negativo & negativo \\
\hline 13 & negativo & positivo & negativo & negativo \\
\hline 14 & negativo & negativo & negativo & negativo \\
\hline 15 & positivo & positivo & negativo & negativo \\
\hline 16 & positivo & negativo & positivo & negativo \\
\hline 17 & positivo & negativo & negativo & negativo \\
\hline 18 & negativo & positivo & negativo & negativo \\
\hline 19 & positivo & positivo & negativo & negativo \\
\hline 20 & negativo & positivo & negativo & negativo \\
\hline 21 & negativo & positivo & negativo & negativo \\
\hline 22 & positivo & negativo & negativo & negativo \\
\hline 23 & negativo & negativo & negativo & negativo \\
\hline 24 & negativo & positivo & positivo & negativo \\
\hline 25 & negativo & positivo & negativo & negativo \\
\hline 26 & positivo & negativo & positivo & negativo \\
\hline 27 & negativo & negativo & negativo & negativo \\
\hline 28 & negativo & negativo & negativo & negativo \\
\hline 29 & positivo & positivo & positivo & positivo \\
\hline 30 & negativo & positivo & negativo & negativo \\
\hline 31 & negativo & positivo & negativo & negativo \\
\hline 32 & negativo & positivo & negativo & negativo \\
\hline 33 & negativo & positivo & negativo & negativo \\
\hline 34 & positivo & positivo & negativo & negativo \\
\hline 35 & negativo & negativo & negativo & negativo \\
\hline 36 & negativo & positivo & negativo & negativo \\
\hline 37 & positivo & positivo & negativo & negativo \\
\hline 38 & negativo & negativo & negativo & negativo \\
\hline 39 & positivo & positivo & positivo & negativo \\
\hline 40 & negativo & positivo & negativo & negativo \\
\hline 41 & positivo & positivo & negativo & negativo \\
\hline 42 & positivo & positivo & negativo & negativo \\
\hline 43 & positivo & negativo & negativo & negativo \\
\hline 44 & positivo & positivo & negativo & negativo \\
\hline 45 & positivo & positivo & negativo & negativo \\
\hline 46 & positivo & positivo & negativo & negativo \\
\hline 47 & positivo & positivo & negativo & negativo \\
\hline 48 & positivo & positivo & negativo & negativo \\
\hline 49 & positivo & positivo & positivo & negativo \\
\hline 50 & positivo & positivo & negativo & negativo \\
\hline
\end{tabular}

